\title{
Çocuklarla İlgili Haberlerin Çocuk Hakları Bağlamında Değerlendirilmesi: KKTC Ulusal Gazeteleri Örneği*
}

\author{
Mualla Nur DOLAR ${ }^{1}$, Nihan KORAN ${ }^{2}$
}

Öz: Bu araştırma, Kuzey Kıbrıs Türk Cumhuriyeti yazılı basınında çocuk içerikli gazete haberlerini, çocuk hakları ve çocukluk imajları doğrultusunda incelemeyi amaçlamaktadır. Araştırmada durum çalışması deseni kullanılmıştır. Araştırmanın örneklemini; Kuzey Kıbrıs Türk Cumhuriyeti'nde günlük olarak yayınlanan ve siyasi bir partiye ait olmayan 8 gazete oluşturmaktadır. Gazetelerin incelenmesinde doküman inceleme yöntemi kullanılmıştır. Verilerin analizinde, içerik analizi ve çocukluk imajlarının analizinde betimsel analiz yöntemi kullanılmıştır. Araştırmanın bulgularına göre, incelenen gazetelerde en fazla adli türdeki haberler bulunmuştur. Çocukların, istismar, ihmal gibi olumsuz durumlarda genellikle mağdur ve kurban temsilleri ile sunuldukları saptanmıştır. Çocuk Hakları Sözleşmesi'nde yer alan katılım hakkının, çoğu haberde görmezden gelindiği ve çocukların kendilerini ilgilendiren haber içeriklerine katılımlarının olmadığı sonucuna ulaşılmıştır. Çocukların korunma haklarına yönelik çok fazla olumsuz haber elde edilmiştir. Çocukluk imajlarına göre çocukların en fazla 'masum' ve 'kurban' imajları ile sunuldukları saptanmıştır. Elde edilen bulgular, literatür desteği ile tartışılmıştır. Çalışma, toplumdaki bütün bireylere öneriler ile son bulmuştur.

Anahtar Sözcükler: Çocuk, Yazılı Basın, Çocuk Hakları, Çocukluk İmajları, Çocuk Hakları İhlalleri, Kuzey Kıbrıs

\section{Evaluation of News on Children in the Context of Children's Rights: The Example of TRNC National Newspapers}

\begin{abstract}
This research aims at examining reports about children in the printed media of the Turkish Republic of Northern Cyprus, in accordance with child rights and image. In the research, the case study pattern is used. The samples of the research consist of 8 newspapers that are published daily and have no political orientation. According to the findings of the research; mostly forensic reports are found in the reviewed newspapers. It is determined that children are generally presented in victim representations in adverse situations such as abuse or neglect. It is concluded that, right of participation mentioned in the Convention on the Rights of the Children is neglected and that children do not take part in reports concerning them. So too many negative reports are obtained about the children's rights of protection. It is determined that children are mostly represented in 'innocent' and 'victim' images according to childhood images.
\end{abstract}

Keywords: Child, Printed Media, Children's Rights, Images of Childhood, Violations of Children's Rights, North Cyprus

* Bu çalışma Mualla Nur Dolar'ın Doğu Akdeniz Üniversitesi Temel Eğitim Bölümü'nde Dr. Öğretim Üyesi Nihan Koran danışmanlığında hazırladığı yüksek lisans tez çalışmasından üretilmiştir.

1 Doğu Akdeniz Üniversitesi, Eğitim Fakültesi, Temel Eğitim Bölümü, Gazimağusa, Kuzey Kıbrıs Türk Cumhuriyeti, mualladolar 94@hotmail.com, ORCID: https://orcid.org/0000-0002-8676-564X

2 Doğu Akdeniz Üniversitesi, Eğitim Fakültesi, Temel Eğitim Bölümü, Gazimağusa, Kuzey Kıbrıs Türk Cumhuriyeti, nihan.koran@emu.edu.tr, ORCID: https://orcid.org/0000-0003-4869-4171
} 
Çocuğun toplumdaki yerinin ortaya çıkarılması konusunda, dünyanın her yerine ve her kesimine bilgi akışı sağlayan kitle iletişim araçları büyük önem arz etmektedir. Toplumun çeşitli alanlarında olduğu gibi kitlesel iletişimde de topluma sunulan çocuk tasvirleri, toplumda hâkim olan çocuk imajlarını yansıtmaktadır (İnal, 2015). Yazılı basın, konuları diğer medya organlarına göre daha derin bir şekilde incelediği için, çocukları içeren haberlerde de konu üzerinde çalışan araştırmacılara destek olabilmektedir (Uzun, 2014). Ayrıca yazılı basın, toplumda yaşanılan olayları yansıttığı için, çocukların hangi türlerde haberlere konu olduklarını, toplumda karşılaştıkları adaletsizlikler ve haksızlıkları belirleyebilmek amacıyla önem arz etmektedir. Haberlerde çocukların yer aldıkları oranlar ve türler, çocukların sunulma biçimleri, çocuk haklarına gösterilen özen, toplum içerisinde yaşayan bireylerdeki çocuk algısına etki etmektedir (Yüksel Özmen, 2012). Toplum içerisinde ciddi olarak algilanan ve tüm sosyo-ekonomik düzeydeki insanların ilgilendiği haberler; bireylerin hangi konularda, ne şekilde düşünmeleri gerektiği konusunda fikir oluşturmaktadır. Geleceğin yetişkin bireyleri olan bugünün çocukları hakkında yapılan doğru olmayan, etiketleyen ve hak ihlallerinin bulunduğu haberler, çocukların şu anki ve gelecekteki hayatlarında telafisi mümkün olmayan etkiler bırakmaktadır (Kahriman, 2013). Bu nedenle çocukların yazılı basında nasıl temsil edildiklerine yönelik başlıca sorunlar; haber içeriklerinde nasıl ve hangi imajlar ile sunulduklarını, hangi haklarının ihlal edilip hangi haklarının korunduğunu ortaya koymaktır (Arslan ve Duğan, 2016).

\section{Çocukluk İmajları}

Çocukluk imajları yetişkinlere çocukların kapasiteleri, gelişimleri, amaçları, toplumdaki yerleri hakkındaki düşünceleri ile ilgili bilgi vermektedir. Kısacası çocukların yetişkinler tarafından nasıl algılandığını ortaya koymaktadır. Her birey kendi tecrübesine dayanarak ve içinde yaşadığı toplumdan, okulda ve evde aldığı eğitimden etkilenerek kendi çocukluk imajını geliştirmektedir. Zaman zaman bireyler sahip oldukları çocukluk imajının farkında olmamakla birlikte, çocuklar açısından yüksek düzeyde yarar sağlayan çocukluk imajının hangisi olduğuna dair fikir yürütülememektedir (Martalock, 2012; Sorin, 2005). Tarihsel olarak üç ana çocukluk imaj1 etkisini sürdürmüştür (Kehily, 2004; Punch, 2003; Sorin, 2005).

a) Masum çocuk imajı: Bu imajda çocuk karar verme kapasitesinden yoksun ve yetişkinler tarafından korunması gereken bireyler olarak görülmektedir. Çocuklar kendi kararlarını almaktansa yetişkin tarafından yönlendirilmekte ve bağımsızlıkları engellenmektedir. Çocuklar saf ve masum olarak görülmekte ve zarar görmemeleri için onlara kendilerini korumaları öğretilmektense yetişkin tarafından korunmaktadırlar.

b) Kötü çocuk imajı: Bazı kaynaklarda bu terim 'şeytan çocuk' olarak karşımıza çıkmaktadır. Bu imaj çocukları kötü, yaramaz ve şımarık olarak tanımlamaktadır. Çocukların düzgün davranmaları için yetişkinler tarafından cezalandırılabileceklerini ön görmektedir. Bu imajda çocukların yapısında problem davranışlar sergileme eğilimi olduğu ve bu eğilimin yetişkinler tarafından düzeltilmesi gerektiği vurgulanmaktadır.

c) Küçük yetişkin imajı: Bu imajda çocuklar yetişkinler gibi davranmakta, giyinmekte ve eğitim görmektedir. Fakat çocuklar yetişkinler gibi karar alma süreçlerine dâhil edilmemektedir.

Aries, 19 ve 20. yüzyılda eğitime yönelik gelişmelerin, toplumun, çocuklara karşı bakış açısını değiştirdiğini belirtmektedir. Bununla birlikte çocuklar toplumda, sosyal-toplumsal birer birey olarak görülmeye başlamışlardır (Kaymaz, 2017). Froebel'in (1837) Anaokulu Hareketi'nden sonra ise çocuklar toplumda masum olarak yer bulmuşlardır. Sorin (2005) çocukların masum imajını araştırmalarında tartışmakta ve çocukların sadece güçsüz, aciz ve korunmaya muhtaç bireyler olmadıklarını aktarmaktadır. Sorin'e (2005) göre çocuklar, sadece korunmaya muhtaç varlıklar değil, aynı zamanda kendi yaşamlarının aktörleri, güçlü ve katılımcı bireyler olarak sunulmalıdır (Avcı ve Pekince, 2018; Sorin, 2005; Woodhead, 2005). Çocukların sunuldukları imajlar, kültüre, toplumlara göre değişiklik gösterse de çoğu toplumda, çocukların korunmaya muhtaç imajlarından dolayı oy kullanmaları, ehliyet alabilmeleri, kendilerini ilgilendiren konularda fikir beyan edebilmeleri gibi konulara, çocukların fikirleri dikkate alınmadan, katılımları sağlanmadan karar verilmektedir (Sorin, 2005). Sorin (2005) çocukların, kendi yaşamlarında pasif bireyler olmalarından yola çıkarak, çocukların toplumda temsil edilme şekillerine yönelik on imaj 
geliştirmiştir. Bunlar; masum çocuk, soylu/mesih çocuk, kötü çocuk, çı̆̆ gibi büyüyen (kartopu) çocuk, kontrolden çıkmış çocuk, küçük yetişkin çocuk, eğitime devam eden yetişkinler, mülk olarak görülen çocuk, kurban çocuk, temsili çocuk imajlarıdır. Masum çocuk, kötü çocuk, eğitime devam eden yetişkinler ve mülk olarak görülen çocuk imajlarının yetişkine bağımlı imajlar olduğu görülmekteyken, soylu/mesih çocuk imajının yetişkinden sorumlu çocuk imajı olduğu görülmektedir. Katılımcı çocuk imajı ise yetişkin ve çocuğun rollerini ve güçlerini paylaştığı çocukluk imajı olarak açıklanmaktadır. Çocukluk çağı ile ilgili geliştirilen on imajın açıklamaları aşağıda belirtilmektedir.

Masum çocuk imajı; Yetişkine bağlı ve bağımlı olan çocuk olarak tasvir edilmektedir. Ayrıca masum çocuk, yetişkinler tarafından korunmaya muhtaç, kendi başına yetersiz ve içi doldurulacak boş bir levha olarak betimlenmektedir (Avc1 ve Pekince, 2018; Sorin, 2005).

Soylu/Mesih (kurtarıcı) çocuk imajı; gelişim kapasitesinden çok fazla sorumluluk üstlendirilen çocukları betimlemektedir. Fedakâr, diğerlerini kurtaracak, süper kahraman benzeri tasvirler bu imajı içermektedir.

Kötü çocuk imajı; tarih öncesi dönemlerde çocukların, doğuştan kötü olarak doğdukları ve ancak ailesinin şiddet uygulamaları ile iyi bir birey olabileceği kanısı görülmektedir.

Çığ gibi büyüyen (kartopu) çocuk imajı; bu imajda tasvir edilen çocukları, Sorin (2005), yetişkinlerden çığ gibi büyüyen, önüne geçilemeyen talepleri ve istekleri olan çocuklar olarak tanımlamıştır. Şımarık, inatçı, istedikleri olmayınca sürekli öfkelenen çocuklar çığ gibi büyüyen imajında yer almaktadır.

Kontrolden çıkmış (kontrol dışı) çocuk imajı; çocuklar rüşvet ve isteklerinin yapılması ile kontrol altına alınabilmekte veya kötü çocuk imajında disipline edilebilmektedirler. Ancak kontrolden çıkmış çocuklar istediklerini yaptırabilmek için, ebeveynleri, öğretmenleri çaresiz bırakacak şekilde yıkıcı davranışlara ve şiddete başvurabilmektedirler.

Küçük (minyatür) yetişkin imajı; bu imajda çocuklar, yetişkinlerden farklı olarak algılanmamaktadır. Eski çağlarda çocuklar, ebeveynleri gibi işçi ve köle olarak, aynı şartlar altında çalışmaktaydılar. Günümüz toplumlarında da çocuk işçilerin ve çocuk askerlerin oluşturulması küçük yetişkin imajını yansıtmaktadır (Haring, Sorin ve Caltabiano, 2019).

Eğitime devam eden yetişkinler imajı; bu imaj, yetişkinlerin yaşamına geçiş için pratik sağlama olarak görülmektedir. Bu imaj, çocukların çocuk olma statülerini görmezden gelmekte ve çocukluk sürecini, yetişkin yaşamında yer alan iş gücü ve sosyal yaşama geçmek için kullanılan bir süreç olarak değerlendirmektedir (Sorin, 2005).

Mülk olarak görülen (metalaşmış) çocuk imajı; bu imaja göre çocuklar sömürülmeye açık nesneler olarak görülmektelerdir (Haring ve diğerleri, 2019). Medya araçlarında, yarışmalarda, yılsonu gösterilerinde reklam amacıyla, sömürülen çocukları tasvir etmektedir (Sorin, 2005).

Kurban (mağdur) çocuk imajı; bu imajda yer alan çocuklar, yoksulluk, açlık, savaş, istismar ve ihmal gibi olumsuz koşullarda mağdur edilen çocuklar olmaktadır (Sorin, 2005).

Temsili çocuk imajı; modern toplumlarda olması gereken çocukluk tasviri üzerinde duran bir imajdır. $\mathrm{Bu}$ imajda ebeveynlerin ve yetişkinlerin görevi, çocukların yaşamlarında ve seçimlerinde onlara rehberlik etmek, karar verme aşamasında yardımcı olmaktır. Eğitim konusunda programlar, çocuklar ile birlikte oluşturulmalı ve çocuğun süreç içerisine aktif katılımı sağlanmalıdır (Sorin, 2005).

Sorin'e (2005) göre imajların oluşturulma amacl; çocukların toplum içerisinde nasıl görüldüklerini ortaya çıkartarak, yeniden yapılandırmak ve bu konuda toplumu harekete geçirmektir (Sorin ve Galloway, 2006).

Yazılı basında yer alan gazete haberlerinde de çocukların yansıtıldığı imajlar/temsiller yer almaktadır. Çocukların haberlerde yer alan imajlarında, çocuk haklarına yönelik bakış açısının ve farkındalığın geliştirilebilmesi açısından önemlidir. Çocukların yazılı basın içeriklerindeki temsillerini araştırmanın çocukların hangi haklarının ihlal edilip hangi haklarının korunduğunu, topluma hangi şekillerde sunulduklarını ve medya içeriklerine katılımlarının ne seviyede olduğunu belirleyebilmek için doğru bir yol 
olduğu düşünülmektedir. Çocukların gazete haberlerinde temsil edilmeleri, yetişkin bireylere oranla daha azınlıkta kalmaktadır. Temsil edildiklerinde ise istismar, ihmal, şiddet içerikli, kurban, çocuk fuhuşu, mahrum kalmış, emek sömürüsü, ensest, şeytan, başarı konusu ve masum gibi tasvirler ile reyting nesneleri olarak sunulmakta oldukları ortaya çıkmıştır (Alankuş, 2012; Altuntaş ve Altınova, 2015; Erdoğan Tosun, 2007; Orçin, 2013; Sayılan ve Çevirgen, 2015; United Nations International Children's Emergency Fund [UNICEF], 2007).

\section{Çocuk Hakları}

Tarihsel süreç içerisinde çocuklara karşı, her toplum tarafından değişik değerler yüklenmiştir. Eski çağdaki toplumlarda aileye ekonomik açıdan yarar sağlayamayan çocuklar, değersiz ve zayıf olarak görülmekteydi. Çocukların, korunmaya muhtaç varlıklar olduğu kanısı, 20. yüzyıldan sonra eksik bulunmaya başlanmıştır. 20. yüzyıldan sonra çocukların korunmanın yanı sıra, aktif katılımları ve ifade özgürlüklerini benimseyen düşünce ortaya çıkmıştır (Atasü Topçuoğlu, 2019). Çocukların daha fazla ilgi ve öneme muhtaç oldukları düşüncesi, devletlerin ve yöneticilerin aileleri denetlemesiyle başlayarak, yasal düzenlemeler ile geliştirilmiştir (Akyüz, 2019). Şirin (2018) çocuklara yönelik hakların oluşturulmasının, sadece çocukların özel ihtiyaçları ve istekleri ile sınırlandırılmadığını, bunun yanı sıra dünyadaki bütün toplumların gelecekleri ile ilgili kaygılanmalarından dolayı da gündeme geldiğini belirtmektedir. Bu duruma çocukların hakları için özel olarak oluşturulan Birleşmiş Milletler Çocuk Hakları Sözleşmesi'nin (BMÇHS) tüm dünya ülkelerince kabul görmesi örnek olarak verilebilir (Şirin, 2018).

BMÇHS 1989 yılında onaylanan, 1990 yılında uluslararası hukuk sistemlerinde yürürlüğe giren ve dünya üzerinde en fazla ülkenin kabul ettiği hak belgesidir (UNICEF, 2007). Sözleşme 0-18 yaşları arasındaki tüm çocukların devlet, toplum, yetişkinler veya akranları tarafından zarar görmesini engellemek üzere oluşturulan, temelde çocukların "yaşamsal, gelişimsel, korunma ve katılım" haklarını garanti altına almayı hedefleyen bir belge niteliği taşımaktadır (Franklin, 2002; Gürkan ve Koran, 2014; Lansdown, 2005; Save the Children, 2010; UNICEF, 2007). Ayrımcilığın önlenmesi ilkesi (Madde 2), yaşama ve gelişme ilkesi (Madde 3), çocuğun yüksek yararının korunması ilkesi (Madde 1) ve çocuğun görüşüne saygı gösterilmesi ilkesi (Madde 12) sözleşmeye yön veren temel değerlerdir (Akyüz, 2001; Hart, 1992; Lansdown 2005).

BMÇHS çocukların dört temel hak alanına vurgu yapılmaktadır. Bu haklar katılım, gelişim, korunma ve yaşamsal haklardır. Sözleşmede ayrıca çocukların medya içeriklerinden korunmasına ve medya içeriklerine katılımlarına yönelik maddeler de yer almaktadır (Genç ve Güner, 2016). BMÇHS'nin 17. maddesinde; toplumlarda kitle iletişim araçları ile yayınlanan bilgilere, programlara çocukların ulaşımının ve katılımının sağlanması, medya organlarının çocukların gelişimini destekleyecek bilgileri yaymalarının desteklenmesi ve çocukların kendilerine zarar verecek içeriklerden korunabilmesi konularına değinilmektedir (BMÇHS, 1989). Çocukların yazılı basında yer alan haberlere katılım gösterebilmeleri, haklarının korunabilmesi, ancak çocuk dostu bir ortamın yeşermesi ile mümkün olabilir. Çocuk dostu bir haber ortamı, ebeveynlerin ve yetişkin bireylerin görüşlerine başvurulduğu kadar, çocuklarında kendilerini içeren haberlere katılımlarının sağlanması ve görüşlerine yer verilmesi ile oluşturulabilir (Akdağ, 2016). Bu konuda medyaya düşen görev, çocukların içeriklere katılımının sağlayabilmesidir. Gelişmiş toplumlarda, çocukların kendilerini ilgilendiren sosyal olay ve olguların katılımcıları olmaları, kendilerini ifade etme özgürlüklerinin olması gibi birçok ihtiyaç ve haklarının olduğu bilinmektedir. Çocukların bu gereksinimlerinin karşılanması, artık sadece ebeveynleri, hak savunucularını, öğretmenleri ve konu ile ilgili uzmanları ilgilendirmekten çıkmış, toplumsal bir boyut haline gelmiştir (Erbay, 2013; Washington, 2010). Ayrıca her alanda, çocukların istismar ve ihmal edilmesi konusunda tedbirler alınarak, toplum içerisinde bu konuda farkındalık sağlanabilmesi, toplumda yaşayan tüm fertlerin çocuk hakları, çocuk istismar ve ihmali konusunda eğitilerek, bilinçli hale getirilmesi bunların önüne geçilebilmesi açısından büyük önem arz etmektedir. Çocukların karşılaştıkları sorunlara yönelik çözümlerin geliştirilmesi, gelecek yaşantılarına 1şık tutarak sorunların geleceğe aktarımını azaltmaktadır (Karakaş ve Çevik, 2016).

Çocuklar geleceği oluşturan bireyler oldukları için, herkes tarafından ilgi çekmekte ve bu yüzden kendileriyle ilgili yapılan haberlerin de haber değerinin yüksek olmasına neden olmaktadırlar. Çocuklar, 
çocukluk döneminde, gelişim bakımından bütün alanlarda diğer yaşlara oranla daha fazla gelişim göstermektedirler. Bu nedenle; çocuklar bir haberin konusu veya öznesi olma durumlarında bile, dikkat edilmezse istismar edilebilmekte, gelişimleri zarar görebilmekte ve hayatı boyunca bu olumsuz izleri taşıyabilmektedirler (Doğrucan ve Yıldırım, 2011; Ziyalar ve Salihoğlu, 2008). Konu ile ilgili yapılan araştırmalarda çoğunlukla, medyanın çocuklar üzerindeki etkisinin araştırıldığı ortaya çıkmaktadır (Bak, 2018; Yüksel Özmen, 2012). Ancak, gazete haberlerinin çocuklara etki etmesi kadar, çocukların haberlerde nasil temsil edildikleri veya edilemedikleri konusunun da önemsenmesi gerekmektedir. Bu nedenle bu çalışmanın amacı Kuzey Kıbrıs Türk Cumhuriyeti yazılı basınında çocuk öznesini içeren gazete haberlerini, çocuk hakları ve çocukluk imajları doğrultusunda incelemektir.

\section{Araştırmanın Önemi}

Bu çalışma günümüz çocuklarının, gelecekte gelişmiş düzeyde toplumlar oluşturabilmeleri için gazete haberleri aracıllğıyla toplumdaki konumlarının ve yer alan temsillerinin belirlenip iyileştirilmesine yönelik çalışmalara katkı sağlayabilmesi açısından önemlidir.

Çalışma, çocukların, gazete haberlerinde teşhir edilen bilgilerini belirleyebilmek açısından önemli görülmektedir. Ayrıca haber içeriklerinde çocukların, hangi konularda daha fazla sunulduklarını ve nitelendikleri durumları ortaya çıkartmak açısından ve çocuklara uygulanan hak ihlallerine, istismarlara karşı farkındalık sağlayabilmek açısından önemli görülmektedir.

Ayrıca çalışma, toplumda konu hakkında farkındalık sağlayarak, hak ihlalleri ve istismarları içeren gazete haberlerine karşı tüm fertleri bilinçlendirmesi açısından önemlidir. Çalışmanın, çocukların temsillerine ve hak ihlallerine yönelik önleyici tedbirlerin alınmasının önünü açması beklenmektedir. Bu tedbirlerin sonucunda çocuk dostu gazete haberlerini, tüm bireylerin okuyarak istismar ve ihmal içeren haberlere karşı bilinçli davranış sergilemelerini sağlayacağı ön görülmektedir. Gazeteciler için çocuk haklarına duyarlı haber yapma konusunda kılavuz niteliğinde bir çalışma olması bakımından da önem arz etmektedir.

\section{Yöntem}

$\mathrm{Bu}$ araştırma, Kuzey Kıbrıs Türk Cumhuriyeti yazılı basınında çocuklarla ilgili yer alan haberlerin çocuk hakları ve çocukluk imajları doğrultusunda incelenip, tartışılmasını amaçlamaktadır. Araştırmanın amacına uygun olarak alt problemler oluşturulmuştur. Bu problemler:

1. Haberlerde çocuklar hangi haber türlerinde yer almaktadırlar?

2. Haberlerin düzeyi (ulusal / uluslararası) nedir?

3. Haberlerde çocuklarla ilgili hangi bilgiler teşhir edilmektedir?

4. Çocuklar haberlerde nasıl (olumlu / olumsuz) sunulmaktadırlar?

5. Haberlerde çocuklar ne şekilde (mağdur / başarı konusu / hak sahibi / reklam aracı vb.) nitelenmektedirler?

6. Haberlerde olumlu ve olumsuz olarak ele alınan çocuk hakları nelerdir?

7. Haberlerde çocuklar hangi çocuk imajları doğrultusunda yansıtılmaktadır?

Araştırmada, amaca ve alt problemlere uygun olarak durum çalışması deseni kullanılmıştır. Durum çalışması, araştırılan durum ve durumları belirlenen sistemde derinlemesine incelemek olarak tanımlanmaktadır (Merriam, 2013). Ayrıca durum çalışmalarında, araştırma dâhilindeki olay ve durumlar doğal şekillerde ve zaman sınırlaması olacak şekilde araştırılmaktadır (Kaleli Yılmaz, 2014). Creswell ve Clark'a (2007) göre durum çalışması ise araştıran kişinin belirli süre ile sınırlandırılmış durum ve durumları, gereken nitel veri toplama araçlarını kullanarak derinlemesine incelediği ve durumlardaki temaların tanımlanarak, detaylı bir şekilde açıkladığı nitel yaklaşımdır. Bu tanımlara uygun olarak araştırma için çocuklarla ilgili gazete haberleri, çocuk hakları ve çocukluk imajları doğrultusunda, belirli süre içerisinde ve doğal haliyle derinlemesine incelendiği için durum çalışması deseni uygun bulunmuştur. 


\section{Araştırmanın Örneklemi ve Veri Toplama Süreci}

Araştırmanın evrenini, Kuzey Kıbrıs Türk Cumhuriyeti'ndeki günlük basım yapan 19 gazete oluşturmaktadır. Araştırmanın örneklemini ise amaçlı rastgele örnekleme yöntemlerinden ölçüt örnekleme yöntemi ile seçilen Kuzey Kıbrıs Türk Cumhuriyeti'nde yayınlanan ve siyasi bir partiye ait olmayan 8 gazete (Haberal Gazetesi, Diyalog Gazetesi, Haberatör Gazetesi, Star Kıbrıs Gazetesi, Kıbrıs Gazetesi, Detay Kıbrıs Gazetesi, Kıbrıs Postası Gazetesi ve Kıbrıs Manşet Gazetesi) oluşturmaktadır. Araştırmanın veri kaynağını, 01.01.2019 tarihinden 01.01.2020 tarihine kadar olan Kuzey Kıbrıs Türk Cumhuriyeti'nde yayınlanan ve siyasi bir partiye ait olmayan gazete haberleri oluşturmaktadır. Araştırma kapsamında gazetelerin internet arşivlerindeki 'çocuk ve çocuk hakları' anahtar kelimeleri ile taranan haberler, doküman inceleme yöntemi ile toplanmıştır. Ayrıca seçilen gazete haberleri, sadece metin odaklı toplanmıştır. Doküman inceleme biriminde, fotoğraflara ve görsellere çalışma kapsamında yer verilmemiştir.

\section{Gazete Haberleri Kodlama Formu}

Araştırmada verilerin sistematik olarak toplayabilmek ve analiz edebilmek için araştırmacı tarafından on maddelik Gazete Haberleri Kodlama Formu oluşturulmuştur. Form oluşturulduktan sonra, güvenirlik ve geçerliliğin sağlanabilmesi için uzman görüşlerine başvurulmuştur. Gazete Haberleri Kodlama Formu, Doğu Akdeniz Üniversitesi Eğitim Fakültesi'nden iki uzmana, İletişim Fakültesi'nden dört uzmana ve Lefke Avrupa Üniversitesi'nden bir uzmana iletilmiştir. Form, uzman görüşlerinden sağlanan geri dönütler ile birlikte tekrar düzenlenmiştir. Uzmanların geri bildirimleri incelenerek, çoğunluğun önerdiği maddelerde değişikliklere ve eklemelere gidilmiştir. Formun tekrar düzenlenen maddelerine bakılacak olursa; 4 . madde olan 'haber içeriğinde çocukların sunulma şekilleri' maddesinde, olumlu ve olumsuz seçeneklerine ek olarak 'değerlendirilemedi' seçeneği eklenmiştir. Formda uzman görüşlerinden önce yer almayan bir madde olan 5 . madde 'haberde yer alan çocuk ifadesinin sayı karşılığı' forma eklenmiştir. Yedinci madde olan 'çocuğun teşhir edilen bilgileri' maddesinden; diğer seçeneği çıkartılmış, cinsiyet seçeneği eklenmiştir. Formun 8. maddesi olan 'haberde çocuğun nitelendiği durum' maddesine; bağış toplama, hak sahibi ve etkinlik katılımcısı seçenekleri eklenmiştir. Uzman görüşlerinden sağlanan geri dönütlere uygun olarak tekrar düzenlenen form, on iki madde ve bir alt maddeden oluşmaktadır.

\section{Verilerin Analizi}

Araştırmada toplanan ve kaydedilen verilerin analiz edilmesinde içerik analizi yöntemi kullanılmıştır. İçerik analizinde ilk olarak elde edilen veriler kodlanarak temalara ayrıştırılmaktadır. Kodlamada, aynı temaları içeren veriler gruplanarak tanımlanmaktadır. Böylece verilerden elde edilen bilgilerin daha anlamlı bir bütün oluşturması sağlanmaktadır (Yıldırım ve Şimşek, 2016). Buna uygun olarak araştırmada, incelenen gazete haberleri Gazete Haberi Kodlama Formu'na uygun kodlanarak temalara ayrılmıştır. Verilerin anlamlı bir hal alabilmesi için Gazete Haberleri Kodlama Formu maddeleri tablo haline getirilerek analiz edilip yorumlanmıştır. Sorin'in (2005) 10 çocukluk imajının analizinde ise betimsel analiz yöntemi kullanılmıştır. Betimsel analiz, çeşitli veri toplama teknikleri ile elde edilmiş verilerin daha önceden belirlenmiş temalara göre yorumlanmasını içermektedir. Bu analiz türünde temel amaç, elde edilen bulguların okuyucuya özetlenmiş ve yorumlanmış bir biçimde sunulmasıdır (Dawson, 2009).

\section{Geçerlik ve Güvenirlik}

Gazete Haberleri analizlerinden elde edilen veriler ışığında Gazete Haberleri Kodlama Formu'nun güvenirliğini ölçmek amacı ile araştırmacılar birbirlerine paralel olarak farklı mekânlarda, rastgele yöntem ile seçilen 7 gazete haberini Gazete Haberleri Kodlama Formu'na göre kodlamıştır. Araştırmacıların kodladığı ve temalara ayrıştırdıkları verilere Miles ve Huberman (1994) güvenirlik formülü uygulanmıştır. Formül sonucu, $57 /(57+5) * 100=\% 91.9$ olarak bulunmuştur. Formülün sonucunun \%70'in üzerinde çıkması çalışmanın güvenilir olduğunu göstermektedir (Miles ve Huberman, 1994). Formülden elde edilen sonuç ile sürdürülmekte olan araştırma güvenilir sayılmıştır.

\section{Etik İlkeler}

Araştırmanın etik prosedürünü sağlamak amacı ile araştırmanın kısa planı (tez önerisi) hazırlanarak 
Doğu Akdeniz Üniversitesi Bilimsel Araştırma ve Yayın Etiği Kurulu'na sunulmuştur. Kuruldan gelen onay ile araştırmanın etik izni alınarak, araştırmaya başlanmıştır.

\section{Bulgular}

Bu bölümde, çocuk ve çocuk hakları anahtar kelimeleriyle, 01.01.2019 tarihinden 01.01.2020 tarihine kadar taranan ve kaydedilen gazete haberlerinden elde edilen veriler, Gazete Haberi Kodlama Formu maddelerine uygun olarak tablo haline getirilip, detaylı bir şekilde ele alınmıştır. Tablolarda yer alan " $\mathrm{n}$ " işareti haber sayısını, "\%" işareti haberlerin yüzdelik oranlarını ve haber örneklerinden sonra yer alan " $\mathrm{H}$ " ifadesi haberin numarasını ifade etmektedir.

Tablo 1

Çocuk ve Çocuk Hakları İ̧erikli Haberlerin Bulunduğu KKTC Gazeteleri

\begin{tabular}{lcc}
\hline Gazeteler & Haber Sayısı (n) & Yüzdelik (\%) \\
\hline Haberatör Gazetesi & 41 & 18.90 \\
Kibrıs Gazetesi & 30 & 13.82 \\
Kibrıs Postası Gazetesi & 30 & 13.82 \\
Kibrıs Manşet Gazetesi & 26 & 11.98 \\
Haberal Kıbris Gazetesi & 25 & 11.52 \\
Diyalog Gazetesi & 23 & 10.60 \\
Detay Gazetesi & 22 & 10.14 \\
Star Kıbrıs Gazetesi & 20 & 9.22 \\
\hline Toplam & $\mathbf{2 1 7}$ & $\mathbf{1 0 0}$ \\
\hline
\end{tabular}

Tablo 1'de, incelenen gazetelerin çocuk ve çocuk hakları ile ilgili haber sayılarına bakılmıştır. En fazla habere ulaşılan gazete, Haberatör Gazetesi'dir. Haberatör Gazetesi'nde içerik ile ilgili bulunan haber sayısı 41'dir. Haberatör Gazetesi'nden sonra en fazla haber sayısından, en az haber sayısına doğru; Kıbrıs Gazetesi ve Kıbrıs Postası Gazetesi 30 haber, Kıbrıs Manşet Gazetesi 26 haber, Haberal Kıbrıs Gazetesi 25 haber, Diyalog Gazetesi 23 haber, Detay Kıbrıs Gazetesi 22 haber ve Star Kıbrıs Gazetesi 20'dir. Gazetelerde çocuk ve çocuk hakları anahtar kelimeleri ile ilgili bulunan haberlere örnek olarak; "...Kolombiya' da yeni bir salgın türü nedeniyle 6 çocuk hayatını kaybetti. Kolombiya Konsey Başkanı'nın yaptığı açıklamaya göre salgın, 10 yaş altındaki çocuklarda ateş, kusma, ishal belirtilerine neden olduğunu belirtti..." (H1) şeklindeki haber verilebilir.

Tablo 2

Çocuk ve Çocuk Hakları İçerikli Haberlerin Kategorilere Göre Haber Türleri Dă̆ılımı

\begin{tabular}{lcc}
\hline Haber Türleri & Haber Sayısı (n) & Yüzdelik (\%) \\
\hline Adli (Kaza, istismar, vb.) & 89 & 41.01 \\
Sosyal Hizmetler & 50 & 23.04 \\
Bilgilendirici Haber (Seminer, söyleşi vb.) & 22 & 10.14 \\
Eğitim & 19 & 8.76 \\
Sosyal Faaliyet & 14 & 6.45 \\
Sanat & 7 & 3.23 \\
Sağllk & 7 & 3.23 \\
Magazin & 4 & 1.84 \\
Bilim/Teknoloji & 4 & 1.84 \\
Spor & 1 & 0.46 \\
\hline Toplam & $\mathbf{2 1 7}$ & $\mathbf{1 0 0}$ \\
\hline
\end{tabular}

Tablo 2'de incelenen gazete haberlerinin hangi türlerde olduklarına bakılmıştır. Gazete haberlerinde en fazla "Adli" kategorisindeki haberlere ulaşılmıştır. Adli haberler; istismar, ihmal, kaza haberlerini içermektedir. Adli türde bulunan toplam haber sayısı 89'dur. Adli kategorisi toplam yüzdeliğin 41.01'ini oluşturmaktadır. Buna göre analiz yapılan KKTC Gazetelerinde, analizin yapıldığı süre içerisinde en fazla kaza, istismar, ihmal benzeri haberler bulunmuştur. Adli kategorisindeki haberlere örnek olarak “...Adana'nın Sarıçam ilçesinde etkili olan sağanak yağıştan dolayı sular altında kalan, yolun karşısına geçmek isteyen 8 yaşındaki Sabri Talhan Kocaman akıntıya kapıldı. Sudan çıkamayan çocuğu yolda bulunan otobüsün şoförü kurtardı. Vatandaşlar 112'yi aradılar, çocuk hastaneye sevk edildi..." (H3) şeklindeki haber verilebilir. 
Sosyal hizmetler haber türü, çocukların refah düzeylerini arttıracak sosyal hizmet uygulamalarında bulunulan haberleri içermektedir. Sosyal Hizmetler haber türünde bulunan toplam haber sayısı 50, yüzdeliği ise 23.04'tür. Gazetelerden Sosyal Hizmetler haber türüne “...LAÜ öğrencileri, Lefkoşa Çocuk Esirgeme Kurumu'na ziyarette bulundular. Temel Eğitim Bölüm Başkanı Çağda Kıvanç; yapılan etkinlikte çocukların eğlenmelerini amaç edindiklerini belirtti. LAÜ öğrencileri etkinlikte farklı kesimdeki çocuklara yardımcı olma fırsatı yakaladılar. Etkinlikte çocuklar, oyunlar ve müzik eşliğinde kaliteli zaman geçirdiler..." (H27) şeklindeki haber örnek olarak verilebilir.

Çocuk ve çocuk hakları içeriği ile ilgili bilgilendirici haberler, bildiriler, yayınlanan mesajlar ve benzeri haberlerin bir araya toplandiğı bir kategori olan Bilgilendirici Haber kategorisinin toplam haber sayısı 22, yüzdeliği ise; 10.14'tür. Bilgilendirici Haber kategorisine, incelenen haberlerden örnek olarak; “...Kamu-Sen 20 Kasım Dünya Çocuk Hakları Günü vesilesiyle bir bildiri yayınladı. Yayınlanan bildiride, çocuk istismarı ve ihmallerin önlenmesi için yasal düzenlemelere ihtiyaç duyulduğu belirtildi. Komite Başkanı Özdemiră̆, çocuk istismarlarının çocukları her açıdan etkileyerek, zihinsel-ruhsal sağlıklarına zarar verdiğini açıkladı..." (H146) şeklindeki haber verilebilir.

Çocuklar için düzenlenen eğitimler, çalıştaylar ve benzeri ögeleri içeren kategori olan Eğitim kategorisinde içerik ile ilgili toplam haber sayısı 19, yüzdeliği ise 8.76'dır. Eğitim kategorisine incelenen haberlerden örnek olarak; “...Cumhurbaşkanlığında 100 öğrencinin katılımıyla 'çocuk çalıştayı' düzenlendi. Kurulan 9 ayrı masada, değerler, sağlık-çevre, dünya, yönetim, sanat, aile, eğitim, iletişim başlıklarını kendi aralarında tartışarak diğer gruplara bu konu hakkında önerilerde bulundular. Cumhurbaşkanı da çocukların stantlarını gezerek 'Haklarımı Biliyorum' kitabını dağıttı..." (H42) şeklindeki haber verilebilir.

Kategorileştirilen bir başka haber türü 'Sosyal Faaliyet' haberleridir. Sosyal faaliyet haberleri; çocukların içerisinde yer aldığı ve çocuklar için düzenlenen etkinlikler, şenlikler, eğlenceler ve benzeri olayların toplandığı haber türüdür. Gazetelerde çocuk ve çocuk hakları içeriği ile bulunan sosyal faaliyet haberlerinin toplam haber sayısı 14, yüzdeliği ise $6.45^{\prime}$ tir. Sosyal faaliyet haber türüne gazetelerden örnek olarak; “...CTP İlçe ve Kadın Örgütü 1 Haziran Dünya Çocuk Günü nedeniyle şenlik düzenledi. Şenlikte çocuklar hem eğlendiler, hem de öğrendiler. Yüz boyama, oyunlar, geri dönüşüm etkinlikleri ve sanat etkinlikleri yer aldı. Çocuklar gün boyunca eğlenceli vakit geçirdiler..." (H127) şeklindeki haber verilebilir.

Tablo 2'de aynı haber sayısı ve aynı yüzdeliğe sahip olan haber türleri; Sağlık ve Sanat haber türleridir. Sağlık kategorisi, hastalık, salgın, pandemi benzeri olayları içermektedir. Sanat kategorisi ise dans, resim, müzik benzeri içerikleri barındırmaktadır. Toplam haber sayıları her iki kategorinin de 7, yüzdelikleri 3.23'tür. Sağlık haber türüne incelenen haberlerden örnek olarak; “...Hindistan'ın yoksul bölgelerinden Bihar Eyaleti'nde 100 'den fazla çocuk beyin iltihabı nedeniyle hayatını kaybetti. 146'dan fazla çocuk ise tedavi görüyor. Doktorlar virüsün liçi meyvesinden bulaştığını düşünüyor. Salgın 95 yılından beri yaz aylarında aynı bölgede meydana geliyor..." (H124) şeklindeki haber verilebilir.

Sanat haber türüne örnek olarak; “...Lefkoşa Belediyesi Orkestrası'na bağlı çocuk korosu yeni yıl konseri verdi. Çocuk korosunun şefliğini; Hale Yaokula, yardımcı şefliğini; Müge Görgül yaptı. LTB Başkanı Mehmet Harmancı; ailelerin çocuklarını müzik dolu yaşama yönlendirmesinin önemini vurgulayarak, koronun başarılı çalışmaları sayesinde daha ileriye gittiklerini açıkladı..." (H25) şeklindeki haber verilebilir.

Haber Türleri kategorilerinde aynı haber sayılarına ve aynı yüzdeliklere sahip diğer iki haber türü; Bilim/Teknoloji ve Magazin Haberleridir. Her iki haber türünün haber sayıları 4, yüzdelikleri; 1.84'tür. Bilim/Teknoloji haber türüne örnek olarak; “...Oyuncak tanıtım videoları çeken 8 yaşındaki Ryan Raji, 26 Milyon Dolarlık geliriyle teknoloji devi Youtube'un bu yıl en çok kazanan çocuğu oldu. BBC'ye göre Teksas'da yaşayan Ryan, her gün Youtube sayesinde milyonlarca çocuğa ulaşıyor..." (H53) haberi örnek verilebilir.

Magazin Haberlerine örnek olarak; “...Son dönemin tartışmalı sosyal medya platformu Tiktok, ABD Donanması tarafından yasaklandı. Tiktok Sosyal Medya Platformu, daha öncesinde çocuk haklarına karşı 
geldiği gerekçesiyle de ABD'de gündeme gelmişti. Şirketin Çin'deki çatı şirketi olan ByteDance, çocuk istismarı ile benzer suçlamalarla gündeme gelmekte..." (H216) haberi örnek verilebilir.

Haber türleri kategorileri içerisinde en az sayıya sahip olan tür spor haber türüdür. Spor haberlerinin toplam sayısı 1, yüzdeliği ise 0.46 'dır. Spor haber türüne gazetelerden örnek olarak; “...̇llkokullar arası KTÖS Satranç Şöleni'nin ikincisi gerçekleştirildi. Atatürk Öğretmen Akademisi'nde yapılan şölen 14 okul 21 takım, 24 öğretmen ve 90 çocuğun katılımı ile gerçekleşti..." (H48) şeklindeki haber verilebilir.

Tablo 3

Çocuk ve Çocuk Hakları İçerikli Haberlerin Düzeyi

\begin{tabular}{lcc}
\hline Gazetelerin Düzeyi & Haber Sayısı (n) & Yüzdelik (\%) \\
\hline Ulusal & 148 & 68.20 \\
Uluslararası & 69 & 31.80 \\
\hline Toplam & $\mathbf{2 1 7}$ & $\mathbf{1 0 0}$ \\
\hline
\end{tabular}

Tablo 3'te incelenen gazete haberlerinin ulusal veya uluslararası şeklinde hangi düzeyde olduklarına bakılmıştır. Ulusal Haberler, Kuzey Kıbrıs Türk Cumhuriyeti'nde geçen haberlerdir. Ulusal Haberlerin toplam haber sayısı 148, yüzdeliği ise 68.20 'dir. Ulusal Haberlere, çocuk ve çocuk hakları anahtar kelimeleriyle incelenen gazetelerden örnek olarak; “...Hamitköy'de saat 11.00 sularında Paşa Sokak üzerinde Hüseyin Ömerağa (59) tarafından kullanılan traktör ile evinin avlusuna girdiği sırada, kucağında oturan Ege Metin Ömerağa (3) dengesini kaybederek traktörden düşüp, tekerleğin altında kalması sonucu ölmüştür..." (H5) şeklindeki haber verilebilir.

Uluslararası Haberler, Türkiye Cumhuriyeti ve diğer ülkelerin haberlerini içeren haberlerdir. Uluslararası haberlerin toplam sayısı 69, yüzdeliği 31.80'dir. Uluslararası Haberlere örnek olarak; “...Kolombiya'da yeni salgın, 6 çocuk hayatını kaybetti. Kolombiya Konsey Başkanı Orlando Moya yaptığı açıklamada, salgının 10 yaş altındaki çocuklarda ateş, kusma, ishale neden olduğunu belirtti. Açıklamasında; 'çocuklar ölüyor, sonuncusu dün öğle saatlerinde öldü. Kimse bunu nedenini açıklamıyor' dedi..." (H1) şeklindeki haber verilebilir.

Tablo 4

Çocuk ve Çocuk Hakları İçerikli Gazete Haberlerinde Çocukların Sunulma Şekli

\begin{tabular}{lcc}
\hline Çocuğun Sunulma Şekli & Haber Sayısı (n) & Yüzdelik (\%) \\
\hline Olumlu & 113 & 52.07 \\
Olumsuz & 104 & 47.93 \\
Değerlendirilemedi & 0 & 0 \\
\hline Toplam & $\mathbf{2 1 7}$ & $\mathbf{1 0 0}$ \\
\hline
\end{tabular}

Tablo 4'te incelenen haberlerde çocukların ne şekilde sunulduklarına bakılmıştır. Çocukların olumlu şekilde sunulduğu gazete haberlerinin sayısı 113, yüzdeliği 52.07'dir. Çocukların olumlu şekilde sunulduğu haberlere örnek olarak; “...Lefkoşa Belediyesi Orkestrası'na bağlı Çocuk Korosu yeni yıl konseri verdi. LTB Başkanı Mehmet Harmancı, ailelerin çocuklarını müzik dolu yaşama yönlendirmelerinin önemini vurgulayarak koronun başarılı çalışmaları sayesinde daha ileriye gittiklerini açıkladı..." (H25) haberi verilebilir.

Çocukların olumsuz şekilde sunulduğu gazete haberlerinin sayısı 104, yüzdeliği 47.93'tür. Çocukların olumsuz şekilde sunulduğu gazete haberlerine örnek olarak; “...Siirt Kurtalan Lisesi müdür ve idarecilerinin, kız çocuklarının etek boylarını ölçerek, hakaret ettikleri ses kayıtları ortaya çıktı. Müdür Fersende Karataş çocuklara psikolojik şiddet uygulandığını kabul ederek birçok okulda aynı durumun yaşandığını aktardı..." (H57) haberi verilebilir.

Tablo 5

Çocuk ve Çocuk İ̧erikli Gazete Haberlerinde Yer Alan Çocuk Ifadesinin Sayı Karşılı̆̆ı

\begin{tabular}{lcc}
\hline Çocuk İfadesinin Sayı Karşılı̆̆ı & Haber Sayısı (n) & Yüzdelik (\%) \\
\hline 2 veya daha fazla & 127 & 58.53 \\
1 & 51 & 23.50 \\
Genel Çocuk Nüfusunu İçerme & 39 & 17.97 \\
\hline Toplam & $\mathbf{2 1 7}$ & $\mathbf{1 0 0}$ \\
\hline
\end{tabular}


Tablo 5'te çocuk ve çocuk hakları içerikli gazete haberlerinde yer alan çocuk ifadesinin kaç çocuğu ifade ettiğine bakılmaktadır. Buna göre Tablo 5; 1, 2 veya daha fazla ve genel çocuk nüfusunu içerme olarak kategorileştirilmiştir. Gazete haberlerinde, haber içeriğinde en çok 2 veya daha fazla çocuktan bahsedilmiştir. İki veya daha fazla çocuğu içeren gazete haberlerinin sayısı 127, yüzdeliği 58.52' dir. İki veya daha fazla çocuktan bahsedilen gazete haberlerine, incelenen haberlerden örnek olarak; “...Evrensel Çocuk Hakları Derneği, içerisinde çocuklarında bulunduğu 50 mültecinin Ercan Havaalanı'nda insani olmayan koşullarda barındığını bildirdi. Ülkemizdeki bu vahim durumun önüne geçilmesine çalışacağımızı bildiririz açıklamasında bulunuldu..." (H212) haberi verilebilir.

Gazete haberlerinde sadece 1 çocuğu içeren haberlerin sayısı 51, yüzdeliği ise 23.50'dir. İncelenen gazete haberlerinde 1 çocuğu içeren haberlere örnek olarak; “...Güzelyurt'ta bir kasapta temizlik amaciyla bulunan çocuk işçi, elini kıyma makinasına kaptırdı. 16 yaşındaki Y.C.K. dün öğleden sonra sağ elini kıyma makinasına kaptırması sonucunda ağır yaralandı..." (H139) haberi verilebilir.

Gazete haberlerinde genel çocuk nüfusunu içeren gazete haberlerinin sayısı 39, yüzdeliği ise 17.98'dir. Genel çocuk nüfusunu içeren haberlere örnek olarak; “... UNESCO 21 Şubat'ı Dünya Anadil Günü ilan etti. Türkiye'de çoğunlukla 2. dil olarak konuşulan Kürtçe üzerinde yoğunlaşmakta. 2002 senesinde İstanbul, Diyarbakır ve Van'da yapılan araştırmanın verilerine göre; anaokulu çocuklarının yüzde 81'inin Türkçesi yetersiz bulunuştur..." şeklindeki haber verilebilir.

\section{Tablo 6}

Çocuk ve Çocuk Hakları İ̧erikli Haberlerde Çocuğun Kişisel Bilgilerine Yer Verilme Durumu

\begin{tabular}{lccccc}
\hline $\begin{array}{l}\text { Çocuğun Kişisel } \\
\text { Bilgilerine Yer } \\
\text { Verilme Durumu }\end{array}$ & $\begin{array}{c}\text { Olumlu Haber } \\
\text { Sayısı (Başarı } \\
\text { vb.) }\end{array}$ & $\begin{array}{c}\text { Olumlu Haber } \\
\text { (yüzdelik) (\%) }\end{array}$ & $\begin{array}{c}\text { Olumsuz Haber } \\
\text { Sayısı (Kaza, } \\
\text { istismar, savaş vb.) }\end{array}$ & $\begin{array}{c}\text { Olumsuz Haber } \\
\text { (yüzdelik) (\%) }\end{array}$ & $\begin{array}{c}\text { Toplam (yüzdelik) } \\
\text { (\%) }\end{array}$ \\
\hline Evet & 34 & 30.91 & 63 & 58.88 & 44.70 \\
\hline Hayır & 76 & 69.09 & 44 & 41.12 & 55.30 \\
\hline Toplam & $\mathbf{1 1 0}$ & $\mathbf{1 0 0}$ & $\mathbf{1 0 7}$ & $\mathbf{1 0 0}$ & $\mathbf{1 0 0}$ \\
\hline
\end{tabular}

Tablo 6 'da çocuk ve çocuk hakları anahtar kelimeleri ile taranan gazete haberlerinde yer alan çocukların kişisel bilgilerine yer verilme durumuna bakılmıştır. Tablo 6, Evet/Hayır şeklinde kategorileştirilmiştir. Çocuğun kişisel bilgilerine yer verilen / yer verilmeyen haberler; olumlu haberler (başarı, etkinlik vb.), olumsuz haberler (kaza, istismar, savaş vb.) şeklinde alt kategorilere ayrılmıştır. Bu sınıflamaya göre çocuğun kişisel bilgilerine yer verilen toplam haber sayısı 97, yüzdeliği ise 44.70'tir. Çocuğun kişisel bilgilerine yer verilen toplam olumlu haber sayısı ise 34, yüzdeliği 30.91'dir. İncelenen olumlu haberlere örnek olarak “...Girne Belediyesi Çocuk Meclisi hayata geçirildi. Kentte yaşayan 9-15 yaş arası çocukların katılımı ile tüm çocuklar temsil edilecek. Çocuk Meclisi yönetim kurulu; Elif Şeker, Mehmet Ali Boncuk, Sudenaz Alev, Nehir Arıcı Sevil Yalçın'dan oluşuyor..." (H28) şeklindeki haber verilebilir.

Çocuğun kişisel bilgilerine yer verilen olumsuz haberlerin toplam sayısı 63, yüzdeliği ise 58.88'dir. Çocuğun kişisel bilgilerine yer verilen olumsuz haberler, kaza haberleri, istismar/ihmal haberleri, savaş haberleri ve benzeri haberlerdir. İncelenen olumsuz haberlere örnek olarak; “... Viyana Devlet Opera Akademisi'nde, çocuklara kilolarını kontrol edebilmeleri için sigara içmelerinin tavsiye edildiği ortaya çıktı. Okulda çocukların giysi bedenleri ile çağırıldıkları ortaya çıktı. Komisyon, çocukların hayatlarının tehlikeye atılmasını araştırıyor..." (H54) şeklindeki haber verilebilir.

Çocuğun kişisel bilgilerine yer verilmeyen haberlerin toplam sayısı 120, yüzdeliği 55.30'dur. Çocuğun kişisel bilgilerine yer verilmeyen haberler de olumlu haberler ve olumsuz haberler şeklinde alt kategorilere ayrılmıştır. Buna göre çocuğun kişisel bilgilerine yer verilmeyen olumlu haberlerin sayısı 76, yüzdeliği ise 69.09'dur. Çocuğun kişisel bilgilerine yer verilmeyen olumlu haberlere örnek olarak; “...Batı Afrika Ülkeleri Ekonomi Topluluğu, çocuk evliliklerini ortadan kaldırmak istiyor. Başkent'te Çocuk Politikası konulu toplantıya UNICEF yetkilileri ve diplomatlar katıldı. Sorumlu Siga Jagne çocuk politikasının bölgesel çocuk haklarını korumaya yardımcı olacağını açıkladı..." (H94) şeklindeki haber verilebilir. 
Tablo 7

Haberlerde Çocuğun Teşhir Edilen Bilgileri

\begin{tabular}{lcc}
\hline Çocuğun Teşhir Edilen Bilgileri & Sayı (n) & Yüzdelik (\%) \\
\hline Teşhir Edilen Bilgi Yok & 120 & 39.47 \\
Yaş & 56 & 18.42 \\
İsim Soy isim & 45 & 14.80 \\
Yaşadı̆̆ı Yer & 42 & 13.82 \\
Okulu & 26 & 13 \\
Cinsiyet & 1 & 1 \\
Yalnizca İsim & 0.55 \\
Ailesinin Kimliği & 0.33 \\
Diğer & 0.33 \\
\hline Toplam & 0 & 0 \\
\hline
\end{tabular}

Tablo 7'de incelenen haberlerde, çocuğun hangi kişisel bilgilerinin teşhir edildiğine bakılmıştır. Haber içeriklerine göre birden fazla madde işaretlenmiştir. Haberlerin içeriğine göre en fazla işaretlenen madde; Tablo 6'da Hayır seçeneği işaretlenen ve çocuğun hiçbir bilgisini teşhir etmiyor anlamına gelen, 'teşhir edilen bilgi yok' maddesidir. Çocuğun teşhir edilen bilgisi olmayan toplam haber sayısı 120, yüzdeliği 39.47'dir. İncelenen gazete haberlerinden teşhir edilen bilgi yok maddesine örnek olarak; “...Gaziosmanpaşa'nın Karlıtepe Mahallesi Cami arasında plakası bulunmayan bir motorlu araç, ateş ederek 2'si çocuk 7 kişiyi yaraladı..." (H9) haberi verilebilir.

Teşhir edilen bilgi yok maddesinden sonra en çok işaretlenen madde; 'yaş' maddesidir. Yaş maddesinde toplam sayı 56, yüzdeliği ise 18.42'dir. Yaş maddesine örnek olarak; “... İstanbul Beylikdüzü'nde hayatını kaybeden 2 ve 4 yaşlarındaki 2 çocuğun ölüm sebebinin domuz gribi olabileceği iddia edildi..." (H2) haberi verilebilir.

Haber içeriklerinde üçüncü olarak en fazla yer verilen madde olan 'İsim- Soy isim' maddesinin toplam sayısı 45, yüzdeliği 14.80'dir. İsim- Soy isim maddesine örnek olarak; “...Hamitköy de saat 11:00 sularında Paşa Sokak üzerinde Hüseyin Ömerağa'nın kullandığı traktör ile evinin avlusuna girdiği sırada, kucağında oturan Ege Metin Ömerağa (3) dengesini kaybederek traktörden düşüp, tekerleğin altında kalarak can verdi..." (H5) haberi verilebilir.

Çocuğun 'yaşadığı yer' maddesinin toplam sayısı ise 42, yüzdeliği 13.82 'dir. Çocuğun yaşadığı yer maddesine örnek olarak; “...Girişimci Çilem Dağıstanlı S.O.S Çocuk Köyü’nde önemli bir etkinlik düzenledi. 5-8 yaş S.O.S çocuk köyünde yaşayan 14 çocuğun katıldığı etkinliği Şekerlokum Sahibi Çilem Dağıstanlı organize etti..." (H38) şeklindeki haber verilebilir.

Çocuğun teşhir edilen farklı bir bilgisi 'Okulu' dur. Teşhir edilen okul bilgisinin toplam sayısı 26, yüzdeliği ise 8.55 'tir. Okul maddesine örnek olarak; “...TRT Çocuk Festivali'nde KKTC'yi temsil edecek öğrenciler Devlet büyüklerini ziyaret ettiler. Şehit Ertuğrul İlkokulu öğrencileri, Mustafa Akıncı, Teberrüken Uluçay, Tufan Erhuman ve Cemal Özyiğit tarafından ayrı ayrı kabul edildiler..." (H44) haberi verilebilir.

Çocuğun teşhir edilen bir başka bilgisi cinsiyettir. Cinsiyet maddesinin işaretlenen toplam sayısı 13, yüzdeliği ise 4.28 'dir. Cinsiyet maddesine örnek olarak; "Afrika da bazı uzuvları kesilerek büyü için kullanılan albino çocukların vahşetinin son kurbanı 7 yaşındaki bir kız çocuğu oldu. Rapora göre, gece yarısı kimliği belirsiz kişilerin kızın evine girip ellerini kestikleri belirlendi..." (H65) haberi verilebilir.

Çocuğun teşhir edilen başka bilgileri 'Yalnızca İsim' ve 'Ailesinin Kimliği' maddeleridir. Her maddeden 1 haber bulunmuştur. Her iki haberin yüzdeliği de $0.33^{\prime}$ tür. 'Fotoğraf' ve 'Diğer' maddelerini içeren teşhir edilen bilgiye ulaşılmamıştır.

Tablo 8

Çocuk ve Çocuk Hakları Içerikli Gazete Haberlerinde Çocuğun Nitelendiği Durum

\begin{tabular}{lcc}
\hline Çocuğun Nitelendiği Durum & Haber Sayısı (n) & Yüzdelik (\%) \\
\hline Mağdur & 115 & 53 \\
Etkinlik Katılımcısı (Sosyal faaliyet, eğitim vb.) & 52 & 23.96 \\
Hak Sahibi & 35 & 16.13 \\
Başarı Konusu & 10 & 4.61
\end{tabular}




0

Tablo 8'de çocuk ve çocuk hakları anahtar kelimelerini içeren gazete haberlerinde çocuğun nitelendiği duruma bakılmıştır. Buna göre çocuğun en fazla nitelendiği durum Mağdur'dur. Mağdur maddesinin toplam haber sayısı 115, yüzdeliği ise 53'tür. Mağdur maddesi; çocuklara karşı hak ihlallerinin yapıldı̆̆ haberleri içermektedir. Mağdur Durumuna incelenen gazete haberlerinden örnek olarak; “... Adana'da 2,5 yaşındaki Cihan pencere önünde oynarken demir korkuluklara asılı kaldı. Çukurova'nın Toros Mahallesinde anne Zeynep Can, okuldan çocuğunu almak için 2,5 yaşındaki Cihan'ı 10 yaşındaki Özgür'e bırakıp evden çıktı. Komşuların ekiplere haber vermesiyle, ekipler çocuğu kurtardılar..." (H66) şeklindeki haber verilebilir.

Çocuğun nitelendiği bir başka durum, 'Etkinlik Katılımcısı' olduğu durumlardır. Etkinlik Katılımcısı Durumu, çocuğun içerisinde yer aldığı sosyal faaliyetler, eğitimler, seminerler, özel gün etkinlikleri gibi durumları kapsamaktadır. Etkinlik Katılımcısı Durumunun toplam haber sayısı 52, yüzdeliği ise, 23.96'dır. Etkinlik Katılımcısı Durumuna örnek olarak; “...LTB Ritim Orkestrası'nda Engelsiz Halk Danslarına katılan özel gereksinimli çocuklara yönelik gezi düzenlendi. Çocuklar hem bilgi aldılar hem de canlıları yerinde görme imkanı buldular..."(H74) haberi verilebilir.

Çocuğun nitelendiği 'Hak Sahibi' maddesinin toplam haber sayısı 35, yüzdeliği 16.13'tür. Çocuğun Hak Sahibi olarak nitelendiği haberlere örnek olarak; “... Lefkoşa Türk Belediyesi Başkanı Mehmet Harmancı, 'Lefkoşa da her çocuğun hakkı var' diyerek Çocuk Meclisi kurulması için çalışmalara başlandığını belirtti. Harmancı; Dünya Çocuk Hakları Günü için mesaj yayınlayarak, 'çocukların sahip oldukları tüm hakları sağlamak için çalıştıklarını' bildirdi..." (H106) şeklindeki haber verilebilir.

Çocuğun 'Başarı Konusu' olarak nitelendirilen haberlerin sayısı 10, yüzdelikleri ise 4.61'dir. Başarı Konusu maddesine örnek olarak; “...KKTC'de faaliyet gösteren Ministry of Dance Okulu öğrencileri Elis Sermaye, Beren Barlasoğlu, Simay Atankum ve Karel Biran Yunanistan'daki Salsa Spring Festivalinde Eurosan Latino Qualifiers elemelerine katıldılar. 8-11 yaş salsa kızlar kategorisinde üstün başarı göstererek şampiyon oldular. Okul öğretmenleri büyük gurur yaşadı..." (H130) haberi verilebilir.

Çocuğun 'Bağış Toplama' adı altında nitelendiği haber sayısı 5, yüzdeliği 2.30'dur. Bağış Toplama haberlerine örnek olarak; “...Lefkoşa Folklor Derneği, Lefkoşa Çocuk Yuvasına bağışta bulundu. Dernek Başkanı Ayda Öztürk; 'Yardıma ihtiyacı olan çocukların yanında bulunmaktan, ihtiyaçlarını karşılamaktan mutluluk duyuyoruz' dedi. Kumanya, kıyafetlerin yanı sıra yumurta ve tavuk eti de teslim edildi..." (H26) haberi verilebilir. Çocuğun diğer bir nitelendiği durum olan 'Reklam Aracı' durumunda haber bulunamamıştır. Bu nedenle Reklam Aracı Durumunda haber sayısı 0’ dır.

Tablo 9

Çocuk ve Çocuk Hakları İçerikli Haberlerde Çocuğun Yer Aldığı Hak Kategorisi

\begin{tabular}{|c|c|c|c|c|c|c|}
\hline Hak Kategorisi & $\begin{array}{c}\text { Olumlu Haber } \\
\text { Sayısı (n) }\end{array}$ & $\begin{array}{c}\text { Olumlu Haber } \\
\text { Yüzdelik (\%) }\end{array}$ & $\begin{array}{c}\text { Olumsuz Haber } \\
\text { Sayısı (n) }\end{array}$ & $\begin{array}{c}\text { Olumsuz Haber } \\
\text { Yüzdelik (\%) }\end{array}$ & $\begin{array}{c}\text { Toplam Haber } \\
\text { Sayısı (n) }\end{array}$ & $\begin{array}{c}\text { Toplam } \\
\text { (yüzdelik) (\%) }\end{array}$ \\
\hline Gelişimsel Haklar & 51 & 40.48 & 2 & 1.23 & 53 & 18.40 \\
\hline Korunma Hakları & 43 & 34.13 & 88 & 54.32 & 131 & 45.49 \\
\hline Katılım Hakları & 24 & 19.05 & 44 & 27.16 & 68 & 23.61 \\
\hline Yaşamsal Haklar & 8 & 6.35 & 28 & 17.28 & 36 & 12.5 \\
\hline Toplam & 126 & 100 & 162 & 100 & 288 & 100 \\
\hline
\end{tabular}

Tablo 9, Birleşmiş Milletler Çocuk Haklarına Dair Sözleşmesi'nde yer alan dört temel hak kategorisini yansıtmaktadır. Hak Kategorileri olumlu haklar ve olumsuz haklar olarak alt başlıklara ayrılmıştır. Gazete Haberlerine göre tabloda birden fazla madde işaretlenmiştir. Hak Kategorilerinin toplam sayısı 288'dir.

Korunma Hakları kategorisinin gazete haberlerine göre bulunan toplam haber sayısı 131, yüzdeliği 45.49'dur. Korunma Hakları; her türlü istismar, ihmal ve taciz vakaların önlenmesi için gerekli bir hak kategorisidir. Korunma Hakları olumlu ve olumsuz olmak üzere iki alt başlıkta toplanmıştır. Olumlu korunma haklarının gazete haberlerine göre toplam haber sayısı 43, yüzdeliği ise 34.13'tür. Olumlu korunma 
hak kategorisine çocuk ve çocuk hakları anahtar kelimeleriyle incelenen gazete haberlerinden örnek olarak; “...Güney Kıbrıs'ta sosyal medya hesabından bir çocuğun fotoğraflarına irkçı yorumlar yapan kadına para cezası verildi. Evlatlık Asya kökenli çocuklarının fotoğrafını sosyal medyasında paylaşan baba, kadının ırkçı yorumlarını Rum Çocuk Haklarını Koruma Komiser' ine şikâyet etti..." (H91) şeklindeki haber verilebilir.

Olumsuz korunma hak kategorisinde bulunan toplam haber sayısı ise 88, yüzdeliği 54.32'dir. Olumsuz korunma hakkı haberlerine örnek olarak; “...Ordu'nun Çatalpınar ilçesinde yaşayan Ö. A. (E-4) adlı erkek çocuğunu darp ederek, cinsel istismarda bulunan Mehmet T. (64) tutuklandı. Ortaköy Mahallesinde evinin önünde oynayan çocuğu ıssız bir yere götürerek istismar ve darpta bulunan Mehmet T. Tutuklandı..."(H4) şeklideki haber verilebilir.

Gelişimsel Hak Kategorisinde gazete haberlerine göre bulunan toplam gelişimsel hak kategorisi haber sayısı 53, yüzdeliği ise $18.40^{\prime}$ tır. Gelişimsel Haklar, çocuğun içerisinde bulunduğu dönemi en elverişli şekilde geçirebilmesini ve tüm yönlerden yeteneklerinin gelişebilmesini sağlayan haklardır. Gelişimsel hak kategorisi olumlu haberler ve olumsuz haberler olarak iki alt basamağa ayrılmıştır. Olumlu gelişimsel hakları içeren gazete haberlerinin sayısı 51, yüzdeliği ise 40.48 'dir. Olumlu gelişimsel hakları içeren gazete haberlerine örnek olarak; “... Lefkoşalılar-Toplumlararası Belediye Koordinasyon Grubu 1 Haziran Dünya Çocuk Gününe özel etkinlik düzenliyor. Etkinlikte, sanat, spor, dans, atölye çalışmaları, çocuk oyunları ve müzik etkinlikleri yer alıyor. Çocuklar etkinlik boyunca eğlenirken aynı zamanda öğrenebilecekler..." (H17) şeklindeki haber örnek olarak verilebilir. Olumsuz gelişimsel hakları içeren gazete haberlerinin sayısı ise 2, yüzdeliğgi 1.23'tür. Olumsuz gelişimsel hakları içeren gazete haberlerine örnek olarak; “... Adana da yakaladıkları çıtır isimli hamile kediyi, köpeğe parçalatan 3 çocuk 1 ay ev hapsi cezası aldılar. Seyhan İlçesinde kediyi köpeğe öldürten H.P. , M.Ü. ve A.Y. birbirlerini suçladılar..." (H76) haberi verilebilir.

Yaşamsal Hak Kategorisinde gazete haberine göre toplam haber sayısı 36, yüzdeliği ise 12,5'dir. Yaşamsal Haklar; beslenme, barınma, giyinme, eğitim, sağlık gibi temel hakları içermektedir. Yaşamsal hak kategorisi de diğer hak kategorileri gibi olumlu haberler ve olumsuz haberler olmak üzere alt başlıklara ayrılmıştır. Olumlu yaşamsal hak haberlerinin toplam sayısı 8, yüzdeliği 6.35 'dir. Olumlu yaşamsal haklara taranan gazete haberlerinden örnek olarak"... Son 3 yılda 23 çocuk evlat edinildi. Sosyal Hizmet Dairesi Müdürü Aydan Başkurt; 'Devlet çocuklar ile ilgili hiçbir konuda tasarruf etmiyor çocuklara veremediğimiz tek şey aile ortamı' dedi. Çocuklara eğitim, sağlık, giyinme, barınma gibi temel konularda en iyisinin sağlandığını bildirdi..." (H20) şeklindeki haber örnek olarak verilebilir. Olumsuz yaşamsal hakların taranılan gazete haberlerine göre toplam haber sayısı ise 28, yüzdeliği 17.28'dir. Olumsuz yaşamsal hakları içeren gazete haberlerine; “... Tokat'ın Erbağ İlçesinde 3 y1l önce TEOG birincisi olan M.Ö. Simeri Kalesinden atlayarak yaşamına son verdi..." (H70) şeklindeki haber verilebilir.

Katılım Hakları kategorisinde incelenen gazete haberlerinde bulunan toplam katılım hakkı ile ilgili haberlerin sayısı 68, yüzdeliği ise 23.61'dir. Katılım Hakları; çocukları ilgilendiren konularda, onlara danışılması ve kendilerini ifade etme özgürlüklerinin bulunduğu hak kategorisidir. Katılım hakları kategorisi de diğer hak kategorileri gibi olumlu haberler ve olumsuz haberler olarak iki alt başlığa ayrılmıştır. Olumlu katılım haklarının gazete haberlerine göre toplam sayısı, 24, yüzdeliği ise 19.05 'tir. Olumlu katılım haklarına incelenen gazete haberlerinden örnek olarak; “... Girne Belediyesi Çocuk Meclisi hayata geçirildi. Kentte yaşayan 9-15 yaş arası çocukların katılımı ile tüm çocuklar temsil edilecek. Çocukların kent yaşamında aktif rol almaları ve söz sahibi olmalarını sağlamak amacıyla ÇHS'ne bağlı ilkelerle çalışılacak..." (H28) şeklindeki haber verilebilir. Olumsuz katılım hakkı kategorisinin toplam haber sayısı; 44, yüzdeliği ise 27.16'dır. Olumsuz katılım hakkına örnek olarak; “...Lefkoşalılar- Toplumlararası Belediye Koordinasyon Grubu 1 Haziran Dünya Çocuk Günü'ne özel etkinlik düzenliyor. Etkinlikte; sanat, spor, dans, atölye çalışmalarının yer alması belirlendi..." (H17) şeklindeki haber verilebilir.

Tablo 10

Çocuk ve Çocuk Hakları İçerikli Haberlerde Çocuğun Sunulduğu Çocukluk Imajları

\begin{tabular}{lcc}
\hline Çocukluk İmajları & Haber Sayısı (n) & Yüzdelik (\%) \\
\hline Masum Çocuk & 181 & 49.32 \\
Kurban Çocuk & 116 & 31.61
\end{tabular}


Tablo 10'da Çocuk ve Çocuk Hakları içerikli gazete haberlerinde çocuğun sunulduğu çocukluk imajlarına bakılmıştır. İncelenen gazete haberlerine göre bulunan toplam çocukluk imajı sayısı 367'dir. Gazete haberleri analiz edilirken birden fazla imaj işaretlenmiştir.

Masum Çocuk çocukluk imajı; yetişkine bağımlı olan, saf çocuğu ifade eder (Sorin, 2005). Buna göre incelenen gazete haberlerinde bulunan toplam masum çocuk çocukluk imajı haber sayısı 181, yüzdeliği ise 49.32'dir.Incelenen gazetelerden masum çocuk imajına örnek olarak; “...Bugün saat 16:00 sularında Çatalköy'de Isabel Ahmed (E-4) havuz içerisinde bulunduğu sırada boğulma tehlikesi geçirmiştir. Çocuk Girne Dr. Akçiçek Hastanesinde yapılan tüm müdahalelere rağmen kurtarılamayarak yaşamını yitirmiştir..." (H11) şeklindeki haber verilebilir.

Kurban çocuk çocukluk imajı, incelenen gazete haberlerinde masum çocuktan sonra en yüksek orana sahip imajdır. Kurban çocuk; savaş, terör, açlık, yoksulluk gibi konularda istismar ve ihmal yaşayan çocukları içermektedir. Kurban çocuk imajını içeren toplam haber sayısı 116, yüzdeliği 31.61'dir. Kurban çocuğa incelenen gazete haberlerinden örnek olarak “...Adana'nın Sarıçam İlçesinde etkili olan sağanak yağıştan dolayı sular altında kalan, yolun karşısında geçmek isteyen 8 yaşındaki Sabri Talhan Kocaman akıntıya kapıldı. Sudan çıkamayan çocuğu, otobüs şoförü kurtardı..." (H3) haberi verilebilir.

Temsili Çocuk imajının incelenen gazete haberlerine göre toplam haber sayısı 30, yüzdeliği ise 8.17'dir. Temsili çocuk, eğitime ve yaşamın her alanına katılan sosyal bir aktördür. Temsili çocuk imajına gazete haberlerinden örnek olarak; “...Girne Evrensel Müzik Derneği Çocuk Korusu, New York Cornegie Hall Festivali'nde Kıbrıs'ı temsil edecek. Koro, Alanya'daki Koro Festivali'nde gösterdiği başarı ile New York Festivali'ne katılmaya ve para ödülüne layık görüldü..." (H32) haberi verilebilir.

Küçük Yetişkin çocukluk imajının incelenen gazeteler içerisinde toplam haber sayısı 13, yüzdeliği ise 3.54'tür. Küçük yetişkinler; beslenme, barınma, çalışma gibi konularda yetişkin ile aynı koşullarda bulunan çocuktur. Küçük yetişkin imajına gazete haberlerinden örnek olarak; “...Pazar akşamı saat 07:30 sularında 2 yaşındaki Kenneth Neil Howard oyun oynamak için evinin bahçesine çıktı. Birkaç dakika sonra babası bahçeye baktığında onu bulamadı. Aile polise haber verdi. 3 gün süren çalışmaların sonunda, çocuk bir madenin yanında bulundu. ..." (H18) haberi verilebilir.

Kötü Çocuk çocukluk imajının incelenen haberlere göre toplam haber sayısı 9, yüzdeliği ise 2.45'tir. Kötü çocuk; çocuğun doğuştan kötü olduğuna inanılan, yaramaz, şiddete başvuran çocuk tasviridir. Kötü Çocuk imajına gazete haberlerinden örnek olarak"...Brezilya'da siyahi bir çocuğa çikolata çaldığı için, soyularak işkence yapılması ülkede tepkiye yol açtı. Siyahi çocuk güvenlik görevlileri tarafından soyularak kırbaçlandı. Halk görüntüleri kameraya aldı..." (H72) haberi verilebilir.

Çocukluk imajları tablosunda diğer iki kategori olan 'Kontrolden Çıkmış Çocuk' ve 'Mülk Olarak Görülen Çocuk' kategorilerinin her ikisinin de toplam haber sayıları 7, yüzdelikleri 1.91'dir. Kontrolden çıkmış çocuk; yetişkini çaresiz bırakan, isteklerini yaptırabilmek için şiddete ve kontrolsüz davranışlara başvuran çocuk tasviridir. Mülk olarak görülen çocuk ise; yetişkinler tarafından nesneleştirilerek tüketilen çocuktur. Kontrolden çıkmış çocuk imajına gazete haberlerinden örnek olarak; “...Gemikonağı'nda 48 yaşındaki Akan Aybers'i darp ederek, cüzdanındaki parayı çalarak soygun yapan 21 yaşındaki A.B ile 14 yaşındaki H.T aleyhine yürütülen soruşturma tamamlandı..." (H120) haberi verilebilir.

Mülk olarak Görülen Çocuk İmajına ise incelenen gazetelerden örnek olarak; “...Prof. Dr. Mesude Atay, Nihat Hatipoğlu'nun sunduğu ramazan programında 13 yaşındaki bir çocuğun Müslüman olmasını, çocuk 
hakları ve çocuk gelişimi açısından değerlendirdi. 'Hatipoğlu 13 yaşındaki çocuğu programına konuk aldı, çocuğu nesneleştirerek, popüler kültüre hizmet etti' dedi..." (H99) haberi verilebilir.

Soylu/Mesih Çocuk İmajında gazete haberlerine göre bulunan haber sayısı 4, yüzdeliği ise 1.09'dur. Soylu/Mesih çocuk; üzerine çok fazla yetişkin sorumluluğu yüklenen, fedakâr, süper kahraman olarak görülen ve diğerlerini kurtaracak güçte sunulan çocuktur. Soylu/Mesih çocuk İmajina gazete haberlerinden örnek olarak; “...Gümüş Kubilay (8) doğduğundan beri hiç kesilmeyen ve kalçasına kadar olan saçlarını kanserle mücadele eden çocuklar için kestirdi. Kubilay; 'Saçım başka çocuklara ümit olsun istiyorum' dedi..." (H81) haberi verilebilir.

\section{Sonuç ve Tartışma}

$\mathrm{Bu}$ bölümde gazete haberleri kodlama formundan elde edilen verilerin sonuçları, literatür desteği ile yorumlanarak, tartışılmıştır. Kuzey Kıbrıs Türk Cumhuriyeti yazılı basınında yer alan haberlerin çocuk hakları ve çocukluk imajları doğrultusunda incelenmesini amaçlayan bu araştırmada ilk olarak çocukların hangi haber türlerinde yer aldığına dair bulgular analiz edilmiştir. Bu analiz sonucunda çocuklara yazılı basında, yoğun olarak istismar ve kaza içerikli adli haberlerde yer verildiği sonucuna ulaşılmıştır. Ayrıca çocukların bu haberlerde sadece 'olay' bağlamında sunulmakta oldukları tespit edilmiştir. İncelenen haberlerin çoğunda çocukların suçlu ve mağdur konumda olmalarının nedenlerine değinilmediği ve olayların nedenlerine yönelik bilgilerin yetersiz olduğu sonucuna ulaşılmıştır. Gencel Bek (2011) çocukların haberlere yansıyan olumsuz durumlarının, sadece olay bazında ele alınmaması gerektiğini, yaşanmış olan bu olayların neden ortaya çıktığına ilişkin konularında üzerinde durulması gerektiğini vurgulamaktadır. Araştırmadan elde edilen bu sonuç, çocukların medyada adli haberler aracılığı ile suçlu veya mağdur olarak temsil edildiklerini düşündürmektedir. Ayrıca elde edilen sonuç Fırat (2016) tarafından gerçekleştirilen araştırma bulguları ile de benzerlik göstermektedir. Fırat (2016) tarafından gerçekleştirilen Çocuk Odaksız Habercilik başlıklı araştırmada da çocuk içerikli haberlerde adli kategorisi en yüksek yüzdeye sahip kategori olarak saptanmıştır. Gazete haberlerinde çocukların istismar, ihmal benzeri konular ile yer bulabilmeleri, toplum içerisinde de istismar, ihmal ve kaza vakalarının çoğunlukta olduğunun göstergesi olarak kabul edilebilmektedir (Ardıç Çobaner, 2015). Çocukların yoğun olarak adli türdeki haberlerde yer almaları ve suçlu, mağdur konumlarında sunulmaları çocukların ilerideki yaşamlarını psikolojik açıdan olumsuz olarak etkileyebilmektedir (Berk, 2013). Bu nedenle sunulan haberler çocukların duygusal açıdan sömürülmelerine neden olmadan ve tiraj kaygısı içermeden sunulmalıdır (Özdemir, 2012). Literatürdeki konu hakkındaki çalışmalara bakıldığında da bu durumun desteklendiği görülmektedir. Ezgi Koman ve Şeyma Özkan'ın Hrant Dink Vakfı önderliğinde "Türkiye Yazılı Basınında Çocukların Temsili" (2018) raporunda; çocukların haberlerde şiddet, kaza, istismar benzeri konularla yer aldıkları zaman 'dramatik ögeler' olarak temsil edildikleri belirtilmiştir. Çocuklar haber içeriklerinde, masum, pasif, kırılgan gibi tasvirlerle sunulmaktadırlar. Bu durum, gazete okuyan bireylerin duygularını ön plana çıkartmak ve ilgilerini çekmek amacıyla yapılmaktadır (Koman ve Özkan, 2018).

Çocukların haberlerde, adli türden sonra en çok 50 haber ile 'Sosyal Hizmetler' türünde haberler ile temsil edildikleri saptanmıştır. Buna göre, Kuzey Kıbrıs Türk Cumhuriyeti'nde çocukların refahı ve mutluluğu için düzenlenen kermesler, atölyeler, sanat, müzik benzeri sosyal hizmet etkinliklerinin çoğunlukta olduğu görülmektedir. İncelenen gazetelerde sosyal hizmet türündeki haberlerin fazla olmasının olumlu açıdan, halkı konu hakkında teşvik etmesi ve bilgilendirmesi yönünden önemli olduğu düşünülmektedir. Ancak incelenen sosyal hizmet türündeki gazete haberlerinin büyük çoğunluğunda çocukların görüşlerine ve haber içeriğine katılımlarına önem verilmediği görülmüştür. Çoğu haberde, çocukların görüşleri alınmamış, çocukların haber içeriğine katılımlarına yönelik röportaj niteliğinde bir adım atılmamışır. İncelenen bazı örneklerde, çocuklar haberin özneleri olmalarına rağmen haber içeriğine katılımlarına yönelik bir metine rastlanmamıştır. Birleşmiş Milletler Çocuk Hakları Komitesi'ne göre çocukların katılım sağlayabilmeleri ve fikirlerini aktarabilmeleri açısından kitle iletişim araçları büyük önem arz etmektedir. Ancak Birleşmiş Milletler Çocuk Hakları Sözleşmesi'nin üzerinden çok fazla yıl geçmiş olmasına rağmen kitle iletişim araçları içerisinde çocuklar hala 'pasif' izleyiciler olmaktadırlar (Erbay, 2013; 
Koman, 2011). Mustola, Sevon ve Alasuutari'nin (2020) Finlandiya gazetesinde çocukların haklarının temsiline yönelik yaptıkları çalışmalarının sonuçlarına göre çocukların kendilerini ilgilendiren etkinlikleri ve olayları içeren haberlerin neredeyse yarısına katılım gösterdikleri, fikirlerinin haberler dolayısıyla aktarıldığı görülmüştür. Bu çalışmada ise çocukların kendilerini ilgilendiren sosyal hizmet etkinliklerinin yer aldığı haberlerde dahi fikirlerinin alınmadığı, ÇHS'nde yer alan katılım hakkına yer verilmediği görülmüştür. Bu durumun nedenleri arasında ülke farklılığı, gelişmişlik düzeyindeki farklılıklar ve eğitim sistemlerindeki farklılıkların yer almakta olduğu düşünülmektedir.

Araştırmada gazete haberlerinin düzeyi ile ilgili bulgulara yönelik incelenen gazete haberlerinin 148'inin ulusal düzeyde olduğu yönündedir. Uluslararası haber sayısı ise 69 olarak saptanmıştır. Araştırma sonucunda ulusal haberlere uluslararası haberlerden daha çok yer verildiği belirlenmiştir. Araştırmada; çocuk ve çocuk hakları ile ilgili gazete haberlerinin genellikle Kuzey Kıbrıs Türk Cumhuriyeti'ndeki çocukları içeren olaylardan ve içeriklerden oluşturduğu sonucuna ulaşılmıştır. Yerel basın araçları, bireylerin yaşadıkları yerdeki olaylar ve gelişmeler konusunda bilgilendirici olması açısından önemli görülmektedir. Buna göre incelenen gazetelerde yer alan çocuk ile ilgili haberlerin çoğunluğunun yerel boyutta olması, Kuzey Kıbrıs Türk Cumhuriyeti'ndeki çocukların sorunları, yaşadıkları olaylar konusunda bilgilendirici olması açısından olumlu yönde değerlendirilmektedir (Gezgin, 2007). Ulusoy Ökeli (2019) tarafından gerçekleştirilen "Yerel Basında Çocuk Odaklı Habercilik" çalışmasının konu hakkındaki bulguları, bu araştırmanın bulgularıyla örtüşmemektedir. Çalışmada, incelenen haberlerin sadece yüzde 5 'inin çocuklarla ilgili olduğu görülmüştür. Ayrıca çalışmada incelenen gazetelerde 53 çocuk içerikli haberden sadece 1 haberde çocukların görüşlerine ve katılımlarına yer verildiği görülmüştür. Araştırmanın sonuçlarına göre çocukların yerel basında yeterince temsil edilmediği ve çocukların katılımlarının sağlanmadığını ortaya çıkmıştır. Bu durum, yerel basında da çocukların yok sayıldığını ve ayrımcılığa uğradığını göstermektedir (Ulusoy Ökeli, 2019).

Araştırma kapsamında, "Gazetelerdeki çocuk içerikli haberlerde çocuklarla ilgili hangi bilgiler teşhir edilmektedir?" araştırma sorusuna yönelik elde edilen bulgulara göre 120 haberde çocukların bilgilerinin teşhir edilmediği görülmüştür. Buna göre incelenen gazetelerin çocukların bilgilerini teşhir etme konusunda olumlu bir yaklaşıma sahip oldukları görülmektedir. Bu durumun Birleşmiş Milletler Çocuk Hakları Sözleşmesi'nde yer alan (Madde 16) çocukların özel yaşamının gizliliği hakkına uygun olduğu düşünülmektedir (UNICEF, 2007). Ayrıca çalışmada, çocukların haberlerde teşhir edilen bilgileri olumlu ve olumsuz içerikli haberlere göre ayrıştırılmıştır. Çocukların yaşadıkları istismar, ihmal ve kaza benzeri olaylar olumsuz teşhir olarak kodlanırken, başarı, etkinlik, sanat, spor ve eğitim benzeri haberler olumlu teşhir olarak kodlanmıştır. Buna göre 63 haberde çocukların bilgilerinin teşhir edilmesinin sakıncalı olduğu saptanmıştır. Çocukların bilgilerinden en fazla 56 haber ile yaş bilgisi teşhir edilmiştir. Bundan yola çıkılarak, haber içeriklerinde çocukların yaş bilgilerinin teşhir edilmesine pek fazla önem gösterilmediği düşünülmektedir. Olumsuz içerikli haberlerde çocukların sadece yaş bilgilerinin bile teşhir edilmesi, çocukların psikolojik sağlıklarına kötü etki edebilmektedir (Aktaş Salman, 2019). Ayrıca 45 haberde çocukların isim ve soy isimleri, 42 haberde yaşadıkları yer, 26 haberde okul bilgileri ve 13 haberde cinsiyetleri teşhir edilmiştir. Bağımsız İletişim Ağı (BİA)'nın “Çocuk Odaklı Habercilik” kitabı çocuklar ile ilgili haber yapılırken hangi etik kurallara dikkat edileceği konusunda gazetecilere ve bu konuda çalışma yapanlara rehber olmaktadır (Aktaş Salman, 2019). Ayrıca UNICEF çocuklara yönelik haberler oluşturulurken hangi etik kodların gerekli olduğu konusunda çalışmalar yapmaktadır (UNICEF, 2007). Buna göre BİA ve UNICEF'ten edinilen bilgiler ışığında, çocukları içeren haberlerde, çocukların isim-soy isimleri değiştirilse hatta kullanılmasa bile çocuğu, ailesini ve kardeşlerini her açıdan riske atacak haber ve fotoğrafları yayınlamamanın en iyisi olacağı belirtilmektedir (Alankuş, 2007). Ayrıca, istismar gibi olumsuz durumlar konusunda haber yapılırken, çocukları etiketleyecek tasvirlerden ve çocukların sosyal yaşamlarında dışlanmalarına sebep olacak tasvirlerden kaçınılması gerekmektedir (Uzun, 2014).

İncelenen haberlerde cinsiyet bilgisinin diğer bilgilere oranla az kullanılması ise Kuzey Kıbrıs Türk Cumhuriyeti'ndeki gazetelerin çocuğa çocuk olarak baktıklarını, cinsiyetçilik bağlamında çocukları ötekileştirmediklerini ve bu konuya karşı önem gösterdiklerini ortaya çıkartmaktadır. Son zamanlarda artış 
gösteren, bir cinsiyeti diğer cinsiyetten üstün ve ya eksik görme anlayışının incelenen gazetelerde az olduğu düşünülmektedir. Çocuk Hakları Bilgi Ağı (The Child Rights Information Network [CRIN]) çocuklar ile ilgili haber yapımında, çocukların cinsiyeti, yaşı, ırkı ve yetenekleri sebebiyle ayrımcllı yapılmamasını ön görmüştür. İncelenen gazetelerin de bu konuda olumlu yönde oldukları düşünülmektedir (CRIN, 2020).

Araştırmadaki "Çocuklar gazete haberlerinde nasıl sunulmaktadır?" sorusuna yönelik elde edilen bulgulara göre çocuklar, incelenen gazete haberlerinde 113 haberde olumlu, 104 haberde olumsuz olarak sunulmuştur. Çocukların olumlu olarak sunuldukları haberlerin daha fazla olduğu tespit edilmiştir. İncelenen gazete haberlerinde olumlu haber içeriklerinde, çocuklar, mutlu, eğlenceli, enerjik ve katılımcı tasvirlerle yer almaktadırlar. Olumsuz içeriklerde ise istismar, ihmal edilmiş, şiddete uğramış olarak tasvir edilmektedirler. İncelenen haberlerde çocukların suç, istismar ve ihmal gibi olumsuz sunulmaları azımsanmayacak kadar büyük olsa da çocukların olumlu olarak sunuldukları, başarılarını işleyen ve yarar sağlayan sosyal sorumluluk etkinliklerine yer veren haberler çoğunlukta bulunmuştur. Çocukların haberlerde olumlu olarak sunulmalarının diğer medya organlarına ve gazetelere örnek olacağı, toplum içerisinde de konu hakkında farkındalık kazandıracağı ve olumlu tasvirlerin diğer bireylere rol model olacağı düşünülmektedir (Ulusoy Ökeli, 2019). Kargi'nın (2013) Kuzey Kıbrıs Türk Cumhuriyeti'nde konu ile ilgili yapmış olduğu çalışmasının bulguları, bu bulguyu destekler niteliktedir. Çocukların gazete haberlerinde yüzde 85 gibi büyük bir yüzdelikle olumlu sunuldukları bulunmuştur. Kuzey Kıbrıs Türk Cumhuriyeti gazetelerinde yapılan benzer bir çalışma olan Işıktaş'ın (2017) çalışması da bu çalışmanın bulgularını destekler niteliktedir. Işıktaş incelediği haberlerde, çoğunlukla çocukların olumlu temsil edildiği haberlere ulaşmıştır. Ancak haberlerin birçoğunda olumlu yaklaşım gösterilse bile haberin diline ve içerik oluşturulmasına yeterince dikkat edilmediği bulunmuştur. Bu çalışmadaki incelenen haberlerde de çocuklar olumlu sunulsalar bile, pasif ve yetişkin bireylere bağımlı olarak tasvir edilmektedirler. Bu durum, çocukların katılımlarının ve düşüncelerinin haberlerde önemsenmediğini düşündürmektedir.

Araştırmada "Gazete haberlerinde çocuklar nasıl nitelenmektedirler?" sorusuna yönelik elde edilen bulgular çocukların, incelenen gazete haberlerinde 115 haber ile en fazla 'Mağdur' durumunda nitelendiklerini göstermektedir. Çalışmanın bulguları, birinci alt problemin bulguları ile tutarlılık göstermektedir. Birinci alt problemde, çocukların gazetelerde en fazla hangi haber türlerinde yer aldıkları sorusuna yanıt aranmıştır. Elde edilen bulgulara göre çocukların en fazla adli haber türünde yani ihmal, istismar ve kaza benzeri haberler ile yer aldıkları ortaya çıkmıştır. Bu alt problemde de çocukların haber içeriklerinde en fazla mağdur durumunda nitelendikleri bulunmuştur. Sonuç olarak, çocukların haber içeriklerinde çoğunlukla adli türdeki haberlerde sunuldukları ve bunu takiben mağdur durumunda nitelendikleri düşünülmektedir. Literatürde de incelenen birçok çalışma bu sonucu destekler niteliktedir. Sutherland, McCormack, Easteal, Holland ve Pirkis'in (2016) Avusturalya'da, çocuklara ve kadınlara yönelik şiddetin medya üzerinde nasıl temsil edildiğine yönelik çalışmalarından edinilen bulgulara göre çocuklara ve kadınlara yönelik çok sayıda şiddet haberi bulunmuştur. Bu da şiddetin medyada çok fazla haber değeri olduğunu göstermiştir. Aynı zamanda çocukların ve kadınların çoğunlukla şiddete uğrayan bireyler olarak mağdur durumunda nitelendikleri ortaya çıkmıştır. Altuntaş ve Altınova'da (2015) çalışmalarında benzer bulgulara ulaşmışlardır. Çocukların medya içerisindeki temsillerinde, çoğunlukla suçlu ve mağdur durumlarında nitelendikleri ortaya çıkmıştır. Sonuç olarak incelenen gazetelerin bulgularına göre BMÇHS'nde yer alan çocukların katılım hakkının, haberlerde önemsenmemesi ve çocukların kendilerini ilgilendiren içeriklerde dahi söz haklarının olmaması nedeniyle çocukların haberlerde susturularak, zavallı, mağdur, başarı konusu gibi temsiller ile yer bulabildikleri düşünülmektedir. Bu durumu geliştirebilmek için, bireylerin haber içeriklerinde sunulan mesajlara yönelik bilinçlenmesi gerektiği düşünülmektedir. Bunun olabilmesi için de bireylere, kurumsal olarak ve devlet iş birliğinde eleştirel medya okuryazarlığ 1 eğitimlerinin verilmesi ve bu konuda toplumda farkındalık yaratılmasının gerekliliği savunulmaktadır (Altuntaş ve Altınova, 2015).

Çocukların mağdur durumundan sonra en fazla nitelendikleri başka bir durum ise 'etkinlik katılımcısı' durumudur. Etkinlik katılımcısı durumu, çocuğun içerisinde yer aldığı sosyal faaliyetler, eğitimler, seminerler, özel gün etkinlikleri gibi durumların sunulduğu haberleri kapsamaktadır. Araştırma 
kapsamında incelenen Kuzey Kıbrıs Türk Cumhuriyeti gazeteleri ve Kuzey Kıbrıs toplumu içerisinde çocuklar için düzenlenen şenlikler, etkinlikler ve eğitimler önemli bir yer teşkil etmektedir. Kutlanan çocuk günleri, çocuk şenlikleri ve çocuklar adına düzenlenen festivaller gazete haberlerinde de önemli bir yer kaplamaktadır. İncelenen 217 haberin 50'si çocukların bu türdeki etkinliklere katılımcı durumunda nitelendikleri haberleri içermektedir. Ancak çocukların 'etkinlik katılımcısı' oldukları haberlerde bile çocukların kendilerinin haber içeriklerine katılımlarının sağlanmadığı düşünülmektedir. Bu durumun BMÇHS'nde yer alan çocuğun katılım hakkı (Madde 12) açısından olumsuz bir durum teşkil ettiği düşünülmektedir. Sözleşme, çocukların da yetişkinler gibi birer birey olduklarının unutulmaması gerektiğini ön görmektedir. Sözleşmeye göre; çocukların kendilerini ilgilendiren etkinliklere, olaylara ve bütün konulara katılımlarının sağlanması ilke haline getirilmelidir (Türkyılmaz ve Kuş, 2014).

Araştırmada "Gazetelerde yer alan çocuk içerikli haberlerde olumlu olarak ele alınan çocuk hakları nelerdir?" sorusuna ve "Gazetelerde yer alan çocuk içerikli haberlerde olumsuz olarak ele alınan çocuk hakları nelerdir?" sorularına da yanıt aranmıştır. Bu sorulara yönelik elde edilen bulgulara göre incelenen haber içeriklerinde olumlu olarak ele alınan en fazla hak 51 haber ile 'gelişimsel haklar' olmuştur. Gelişimsel hakların olumsuz olarak yer aldığı haber sayısı ise 2' dir. Bu bulgulara göre incelenen gazetelerde çocukların gelişimsel haklarını olumlu yönde etkileyecek haberler yapıldığı söylenebilmektedir. Gelişimsel haklar, bireylerin fiziksel, psikolojik, yetenek ve beceri gibi tüm alanlarda gelişim göstermeleri ile ilgili olan haklarıdır (Ardıç Çobaner, 2015). Gazetelerin çocukların her açıdan gelişim sağlayabilecekleri alanlara yönelik yapılan haberlerin fazla olması, basın kuruluşlarının çocuklara ve çocukların haklarına gereken önemi verdiklerini düşündürmektedir (Şirin, 2011). Bulgular konu hakkında yapılan bir çalışma ile farklılık göstermektedir. Ardıç Çobaner'in (2015) mülteci çocukların yazılı basında temsiline yönelik gerçekleştirdiği çalışmasında, ÇHS'nde yer alan gelişim haklarının haber içeriklerinde yeterince yer bulamadığı sonucu ortaya çıkmıştır. Buna göre Kuzey Kıbrıs Türk Cumhuriyeti yazılı basınında ve toplumunda çocukların gelişimsel haklarına yönelik yapılan etkinliklerin ve etkinliklere yönelik haberlerin iyi yönde oldukları düşünülmektedir.

Çocukların 'Korunma Hakları' ile ilgili 217 haber içerisinde olumlu olarak sadece 43 haber tespit edilmiştir. Korunma hakkının olumsuz olarak yer aldığı haber sayısı ise $88^{\prime}$ dir. Bu da çocukların istismar, ihmal, kaza benzeri durumlarda korunma haklarının çok fazla önemsenmediğini düşündürmektedir. Medya organlarının birincil görevi toplumu bilgilendirmek, eğitmek ve kamuoyu oluşturmaktır. Bu nedenle çocukların korunma haklarının toplum içerisinde de olumlu yönde ilerlemesi için ilk olarak medyanın, çocuk haklarına önem vermesi ve farkındalık sağlayıcı içerikler üretmesi gerektiği düşünülmektedir (Uzun, 2014). Ziyalar ve Salihoğlu (2008) çalışmalarında çocukların hakları konusunda yasalar oluşturulduğunu, ancak bu yasalara rağmen çoğu haberde çocukların isimlerinin ve görüntülerinin kullanılmakta olduğunu belirtmişlerdir. Yıldız'da (2018) çocukların hakları ve korunmaları ile ilgili yasalar hakkında iyileştirme çalışmaları yapılması gerektiğini vurgulamaktadır.

Çocukların sözleşmede yer alan 'Katılım Hakları' konusunda ise bulgulara göre olumlu olarak sadece 24 haber elde edilirken, çocukların haber içeriklerine ve gerçekleşen olaylara katılmaları gerekirken, katılım göstermedikleri olumsuz katılım haklarının sayısı ise 44'tür. Bu bulgular, 1989 yılında imzalanan Çocuk Hakları Sözleşmesi'nin maddelerinin günümüzde bile hala yeteri düzeyde toplum ve medya organlarınca kabul görmediğini ve maddelere tam olarak uyulmadığını göstermektedir. Çocukların katılım hakları, sözleşmenin birçok maddesinde dile getirilmiştir. Sözleşmenin 12. maddesi. "Her çocuk kendi fikrini, görüşünü ifade etme ve kendisini ilgilendiren tüm konulara katılım gösterme hakkına sahiptir." Şeklindedir (BMÇHS, 1989). Koman ve Özkan (2018) "Çocuk Hakları ve Medya" makalesinde, çocukların katılım haklarının günümüzde hala aktif kullanılamamasının nedenleri ile ilgili; Türkiye'de çocukların birey olarak görülmediklerini, yetişkinlerin çocuklar hakkında karar verdiklerini, ayrıca çocukların oy kullanamamaları ve haklarını koruyabilmek için hukuki süreçlere aileleri olmadan başvuramamaları gibi etkenleri göstermiştir. Belirtilen etkenler ülkemizde çocukların katılım haklarının hala pasif durumda kaldığını göstermektedir. Öte yandan sözleşmenin 13. ve 14. maddelerinde de çocukların kendi görüşlerini aktarabilmeleri, içeriklere katılım gösterebilmeleri konuları üzerinde durulmaktadır (Turanlı, 2004). 
Çalışmada, çocukların 'Yaşamsal Haklar' kategorisinde de yeteri kadar olumlu temsil edilmediği tespit edilmiştir. İncelenen haberlerde olumlu olarak yansıtılan yaşamsal hakların haber sayısı 8 iken, olumsuz olarak yansıtılan haber sayısı ise 28 olarak bulunmuştur. BMÇHS'nin 6. maddesi yaşama hakkı ile ilgilidir (BMÇHS, 1989). Ayrıca Sözleşmenin 27. maddesi de çocukların tüm açılardan, toplum içerisinde gelişebilmesini ön gören, yeterli yaşam seviyesine haklarının bulunduğu ile ilgilidir (BMÇHS, 1989). Ancak çalışmanın bulgularına göre, incelenen gazetelerde ve toplumsal olaylarda çocukların yaşamsal haklarının yeterli düzeyde olmadığı görülmektedir. UNICEF'in (2012) konu ile ilgili yapmış olduğu bir araştırmasının sonuçlarına göre dünyadaki 5-6 yaşlarındaki çocukların çoğunluğunun, hala önlenebilir sebeplerden ötürü yaşamsal haklarının olumsuz yönde ilerlediği ve açlık, sağlık gibi konulardan dolayı hayatlarının son bulduğu ortaya çıkmıştır.

Araştırmada "Gazete haberlerinde çocuklar hangi çocuk imajları doğrultusunda yansıtılmaktadır?" sorusuna da yanıt aranmıştır. Konu ile ilgili elde edilen bulgulara göre; incelenen gazetelerdeki haberlerin, büyük bir çoğunlukla 181 haber ile masum çocuk imajına ve 116 haber ile kurban çocuk imajına yer verdikleri görülmüştür. $\mathrm{Bu}$ bulgu, diğer alt problemlerin bulgularıyla uyumluluk göstermektedir. Çocukların adli türdeki haberlerde çok fazla sunulmaları ile çocukların masum ve kurban olarak sunulmalarının ilişkili olduğu düşünülmektedir. Çocuklar içeriklerde büyük bir çoğunlukla 'masum' olarak tasvir edilmektedirler. Bu durum, haberlerde çocukların 'duygusal malzeme' ve 'sevimlileştirilerek' kullanıldıklarını düşündürmektedir. Sorin'e (2005) göre; çocukların masum olarak tasvir edilmeleri, onları güçsüz, aciz ve yetişkinler tarafından korunmaya muhtaç olarak yansıtmaktadır. Ayrıca Sorin, BMÇHS'nde çocukların korunmalarına yönelik haklarının ön planda tutulmasını eleştirmektedir. Çocukların içeriklerde 'sadece' masum, korunmaya muhtaç varlıklar olarak değil, aynı zamanda kendi yaşamlarının oyuncusu, güçlü ve katılımcı birer birey olmaları gerektiğini vurgulamaktadır (Avcı ve Pekince, 2018; Sorin, 2005; Woodhead, 2005). Kuzey Kıbrıs Türk Cumhuriyeti'nde incelenen gazetelerde de aynı durum ön plana çıkmaktadır. Çocukların haber metinlerinde çoğu zaman korunmaya muhtaç, masum ve güçsüz bireyler olarak tasvir edildikleri görülmüştür.

Çocukların kurban imajıyla tasvir edildikleri 116 haberin, azımsanmayacak kadar fazla olduğu düşünülmektedir. Çocukların haber içeriklerinde fazlaca kurban olarak nitelendirilmeleri, çocuklar ile ilgili haberlerin 'dramatize' edilerek haber değerinin yükseltilemeye çalışıldığı düşündürmektedir (Aktaş Salman, 2019). Green'in (2009) gazetelerde çocuk hakları ve eşitlik üzerine yapmış olduğu çalışması, konu ile tutarlılık göstermektedir. Araştırmada, çocukların gazete haberlerinde genellikle, kurban ve mağdur konumunda sunuldukları bulunmuştur. Ayrıca Arcan (2011) tarafından yapılan çalışmada da, çocukların istismar, ihmal benzeri yaşadıkları olumsuz durumlarda medya içerisinde, kurban ve ya mağdur olarak yer aldıkları görülmüştür. İncelenen gazetelerin bulgularına göre çocukların mağdur oldukları durumlarda genellikle 'kurban' imajında yer aldıkları görülmüştür.

Çocukluk imajlarından 'temsili çocuk' (katılımcı) imajına yönelik bulunan haber sayısı toplam haber sayısının sadece \%8.17'sini oluşturmaktadır. Bu durum çocukların katılımlarına yönelik araştırma sorusu ile tutarlılık göstermektedir. İncelenen bulgularda, çocukların haber içeriklerine katılımlarının fazla olmadığı ve kendilerini içeren konularda fikir beyan etmedikleri görülmüştür. Temsili çocuk imajı konusunda da çok fazla haber bulunamamasının, bu durumu destekler nitelikte olduğu düşünülmektedir. Yüksel Özmen'in (2012) çalışma bulguları konuyu destekler niteliktedir. Çalışmasında sadece 27 haber içeriğinde çocukların katılımlarının önemsendiği, fikirlerinin alındığı görülmüştür. BMÇHS'nde de çocukların katılım haklarına fazlaca önem verilmektedir. Çocukların katılımlarına yönelik, medya çalışanlarını, yöneticileri bilinçlendirici ve farkındalık oluşturucu çalışmaların yapılmasının gerekli olduğu düşünülmektedir.

Araştırma bulgularının sonuçlarına göre araştırmanın örneklemine alınan gazetelerin incelenen süredeki haberlerinde; adli türdeki yani istismar, ihmal ve kazaya yönelik haberler çoğunlukta bulunmuştur. Bunu takiben çocuklar haber içeriklerinde en fazla mağdur ve kurban durumları ile sunulmuştur. Bu durum medyanın çocukların yaşamış oldukları olumsuz durumlarda; onları, mağdur ve kurban temsilleri ile sunarak konunun haber değerini arttırmaya çalıştığını düşündürmektedir (Arcan, 2011; Genç ve Güner, 2016). Çocukların BMÇHS'nde yer alan haklarına bakılan bulgularda, çocukların korunma haklarının 
olumsuz yönde çok fazla artış gösterdiği görülmektedir. Bu konuda incelenen gazetelerin, çocukların haklarının korunması konusunda farkındalık çalışmaları ve gazetelerde konu hakkında içerikler üretmeleri önerilmektedir (Uzun, 2014; Yıldız, 2018). Ayrıca, incelenen gazetelerde çocukların teşhir edilen bilgilerinin olmadığ1 haberlerin sayısının fazla olması, gazetelerin bu konuya önem verdiklerini ve hassasiyet gösterdiklerini düşündürmektedir. Ayrıca haberlerin içeriklerinin, neredeyse hepsine çocukların katılımlarının sağlanmadığı görülmüştür. Haberler yapılırken, çocuklar ile röportaj yapılması, çocukların kendilerini ilgilendiren konularda fikirlerinin alınması önerilmektedir (Koman ve Özkan, 2018).

\section{Öneriler}

Araştırma sonucunda elde edilen bulgular ışığında; haber oluşturan bireylerin, çocuk odaklı habercilik ve çocuk hakları konuları hakkında, toplum içerisinde farkındalık yaratılması amacıyla çalışmalar, yazılar ve makaleler düzenlemeleri önerilmektedir. Haber metinleri yazılırken çocukları içeren istismar, ihmal ve kaza haberlerini sadece olay odaklı sunulmaması, olayın neden meydana geldiği ve bir daha meydana gelmemesi için neler yapılabileceğine yönelik yazılmaları önerilmektedir. Çocukların hakları ile ilgili yazıların gazetelerde arttırılması ve konu hakkında topluma farkındalık kazandırılması önerilmektedir. Çocukların, okul öncesi dönemde medya okuryazarlığı, medya içerisindeki haklar ve ihlaller konusunda bilgi sahibi olmaları, gelecek yaşantılarında kendi haklarını koruyabilmelerinin ve savunabilmelerinin alt yapısını oluşturacağından, okul öncesi alanında çalışan öğretmenlere, sınıflarında konu hakkında çalışmalar yapmaları önerilmektedir.

\section{Yazar(lar)ın Beyanı}

Araştırmacıların katkı oranı beyanı: Birinci yazar verilerin toplanması, verilerin analizi ve raporlaştırma aşamalarında sorumlu yazardır. İkinci yazar araştırmanın tasarlanması ve veri toplama aracının oluşturulması aşamalarında etkin bir rol üstlenmiştir.

Etik Kurul Kararı: Araştırmanın etik prosedürünü sağlamak amacı ile araştırmanın kısa planı (tez önerisi) hazırlanarak Doğu Akdeniz Üniversitesi Bilimsel Araştırma ve Yayın Etiği Kurulu'na sunulmuştur. Kuruldan gelen onay ile araştırmanın etik izni alınarak, araştırmaya başlanmıştır.

Çatışma beyanı: Makalenin yazarları bu çalışma ile ilgili taraf olabilecek herhangi bir kişi ya da finansal ilişkileri bulunmadığını dolayısıyla herhangi bir çıkar çatışmasını olmadığını beyan ederler.

Destek ve teşekkür: Çalışmada herhangi bir kurum ya da kuruluştan destek alınmamıştır.

\section{Kaynaklar}

Akdağ, Ç. (2016). Yeni medyada çocuk haberciliği: "Milliyet çocuk", "Hürriyet çocuk" ve "Cicicee çocuk deyince" sayfalarının incelenmesi. Galatasaray Üniversitesi İletişim Dergisi, (25), 155-180.

Aktaş Salman, U. (2019). Haberde çocuk: çocuk odaklı habercilik elkitabı. İstanbul: IPS İletişim Vakfı.

Akyüz, E. (2001). Çocuk hakları sözleşmesinin temel ilkeleri 1şı̆̆ında çocuğun eğitim hakkı. Milli Eğitim Dergisi, (151), 3-24.

Akyüz, E. (2019). Çocuk hukuku. Ankara: Pegem Akademi.

Alankuş, S. (2007). Kadın odaklı habercilik. İstanbul: IPS İletişim Vakfı Yayınları.

Altuntaş, O. ve Altınova, H. H. (2015). Türkiye'de risk altındaki çocukların ana akım basında temsili. Ergoterapi ve Rehabilitasyon Dergisi, 3(2), 59-70.

Arcan, H. E. (2011). "Medya bă̆lamında çocuk hakları", anne-baba, öğretmen ve medya çalışanları için el kitabı çocuk hakları ve medya. İstanbul: Çocuk Vakfı Yayınları.

Ardıç Çobaner, A. (2015). Çocuk hakları bağlamında Suriyeli mülteci çocukların haberlerde temsili. Marmara İletişim Dergisi, (24), 27-54. 
Arslan, A. ve Duğan, Ö. (2016). Suça yönelmiş çocukların medyada temsili: Bir alan araştırması. Gümüşhane Üniversitesi İletişim Fakültesi Elektronik Dergisi, 4(1), 303-325.

Atasü Topçuoğlu, R. (2019). Türkiye'de göçmen çocukların katılım hakkı. İnsan ve Toplum Bilimleri Araştırmaları Dergisi, 8(1), 408-430.

Avcı, N. ve Pekince, P. (2018). Çocukların çocukluğa bakış açıları. Eğitim ve Bilim Dergisi, 43(196), 1-25.

Bak, G. (2018). 1980’li yıllardan günümüze Türk yazılı basınında çocuk olgusu. İnif E-Dergi, (2), 163-188.

Berk, L. E. (2013). Child development (9. bs.). Boston, MA: Pearson.

Birleşmiş Milletler Çocuk Haklarına Dair Sözleşme. (1989). 19.07.2020 tarihinde http://haberdecocuk.org/mevzuat/uluslararasi-mevzuat/cocukhaklarinadairsozlesme/adresinden erişildi.

Child Rights International Network. (2020). Oslo conferance report. 30.07.2020 tarihinde https://archive.crin.org/en/docs/oslo.pdf adresinden erişildi.

Creswell, J. ve Clark, V. L. (2007). Understanding mixed methods research. J. Creswell (Ed.), Designing and conducting mixed methods research (s.1-19) içinde. Thousand Oaks, CA: Sage.

Dawson, C. (2009) Introduction to research methods: A practical guide for anyone undertaking a research project (4. bs.). Oxford: How to Books.

Doğrucan, A. ve Yıldırım, Z. (2011). Yazılı basında çocuk istismarı haberlerinin incelenmesi: (Cumhuriyet, Hürriyet, Posta, Sabah, Yeni Şafak ve Zaman gazeteleri örneğinde). Uşak Üniversitesi Sosyal Bilimler Dergisi, 4(2), 176-194.

Erbay, E. (2013). Çocukların katılım hakkı üzerine bir Türkiye değerlendirmesi. İnsan ve Toplum Bilimleri Araştırmaları Dergisi, 2(1), 38-54.

Erdoğan Tosun, G. (2007). Çocuklar ve çocuk haklarının medyada temsili. Çocuk Odaklı Habercilik (s.172-195) içinde. İstanbul: IPS İletişim Vakfı Yayınları.

Fırat, F. (2016). Çocuk odak'sız' habercilik: İnternet gazetelerinde çocuk içerikli haberlerin sunumu ve etik ihlaller. Gümüşhane Üniversitesi İletişim Fakültesi Elektronik Dergisi, 4(2), 817-833.

Franklin, B. (Ed.) (2002). The new handbook of children's rights: Comparative policy and practice. London: Routledge.

Gencel Bek, M. (2011). Ataerkillik, piyasa ve mesleki değerler: medyada aile içi şiddetin temsili ve üretim pratikleri. S. Sancar (Ed.), Birkaç arpa boyu... 21. yüzyıla girerken Türkiye'de feminist çalışmalar (s. 649-678) içinde. İstanbul: Koç Üniversitesi Yayınları.

Genç, S. Z. ve Güner, F. (2016). Çocuk hakları bağlamında medyaya ilişkin aile görüşleri (Çanakkale ili örneği). Uşak Üniversitesi Sosyal Bilimler Dergisi, 9(2), 1-23.

Gezgin, S. (2007). Türkiye'de yerel basın. İstanbul: İstanbul Üniversitesi İletişim Fakültesi Yayınları.

Green, A. A. (2009). Children's rights and equality in the newspapers. England: Children's Rights Alliance.

Gürkan, T. ve Koran, N. (2014). 36-72 aylık çocuklar için okul öncesi eğitim programının çocuğun katılım hakkına yer verme durumu açısından incelenmesi. Journal of Teacher Education and Educators, 3(2), 203226.

Haring, U., Sorin, R. ve Caltabiano, N. (2019). Reflecting on childhood and child agency in history. Palgrave Communications, 5(1), 1-9.

Hart, R. (1992). Children's participation: From tokenism to citizenship. Innocenti Essays. 4.

Işıktaş, S. (2017). KKTC yazılı basınında çocuk haklarının temsili üzerine bir analiz çalışması. Journal of Awareness, (3), 29-34. 
İnal, K. (2015). Türkiye'de çocukluk: Nereye!. S. Akçalı (Ed.), Çocuk ve medya (s.13-51) içinde. Ankara: Nobel Yayıncilik.

Kahriman, G. (2013). Yazılı ve görsel basında çocuk haberlerinin seçiminde eşik bekçilerinin rolü (Yayınlanmamış yüksek lisans tezi). Arel Üniversitesi, İstanbul.

Kaleli Yılmaz, G. (2014). Durum çalışması. M. Metin (Ed.), Kuramdan uygulamaya eğitimde bilimsel araştırma yöntemleri (s. 261-285) içinde. Ankara: Pegem Akademi.

Karakaş, B. ve Çevik, Ö. (2016). Çocuk refahı: Çocuk hakları perspektifinden bir değerlendirme. Gazi Üniversitesi İktisadi ve İdari Bilimler Fakültesi Dergisi, 18(3), 887-906.

Karg1, E. (2013). Analyzing "child" stories in cyprus newspaper regarding the "child image in Cyprus culture". Cypriot Journal of Educational Sciences, 8(2), 192-196

Kaymaz, Ç. (2017). Özel gereksinimliliği içeren Türkçe ve çeviri resimli çocuk kitaplarının incelenmesi (Yayınlanmamış yüksek lisans tezi). Hacettepe Üniversitesi, Ankara.

Kehily, M. J. (2004). Understanding childhood: An introduction to some key themes and issues. M. J. Kehily (Ed.), An introduction to childhood studies (s.1-16) içinde. UK: Mc Graw Hill.

Koman, E. (2011). Çocuklarla birlikte başka bir medya, çocuk hakları ve medya kitabı. İstanbul: Çocuk Vakfı Yayınları.

Koman, E. ve Özkan, Ş. (2018). Çocuk hakları ve medya Türkiye yazılı basınında çocukların temsili. İstanbul: Hrant Dink Vakfi.

Lansdown, G. (2005). Çocukların gelişen kapasiteleri. Birleşmiş Milletler Çocuk Fonu (UNICEF): İtalya.

Martalock, P. L. (2012). “What is a wheel?" The image of the child: Traditional, project approach, and reggio Emilia perspectives. Dimensions of Early Childhood, 40(3), 3-11.

Merriam, S. B. (2013). Nitel araştırma: Desen ve uygulama için bir rehber. Ankara: Nobel Yayınları.

Miles, M, B. ve Huberman, A. M. (1994). Qualitative data analysis: An expanded Sourcebook. Thousand Oaks, CA: Sage.

Mustola, M., Sevon, E. ve Alasuutari, M. (2020). Representation of children's views in Finnish newspaper media across three decades. BARN, 37(3-4), 163-175.

Orçin, G. (2013). Yazılı basında suça sürüklenen çocukların sunumu üzerine bir inceleme (Yayınlanmamış yüksek lisans tezi). Marmara Üniversitesi, İstanbul.

Özdemir, E. E. (2012). Çocuk istismarı haberlerinin yazılı basında sunumu (Yayımlanmamış yüksek lisans tezi). Gazi Üniversitesi, Ankara.

Punch, S. (2003). Childhoods in the majority world: Miniature adults or tribal children?. Sociology, 37(2), 277295.

Save the Children. (2010). Putting children at the centre a practical guide to children's participation. UK: International Save the Children Alliance.

Sayılan, G. ve Çevirgen, N. (2015). Yazılı basında çocuk temsilleri: Bir bekleme salonu olarak çocukluk. İletişim ve Diplomasi Dergisi, (2), 97-115

Sorin, R. (2005). Changing images of childhood reconceptualising early childhood practice. International Journal of Transitions in Childhood, 1, 12-21.

Sorin, R. ve Galloway, G. (2006). Construct of childhood: Constructs of self. Children Australia, 31(2), 12-21.

Sutherland, G., Mccormack, A., Easteal, P., Holland, K. ve Pirkis, J. (2016). Media guidelines for the responsible reporting of violence against women: A review of evidence and issues. Australian Journalism 
Review, (38), 8-17.

Şirin, M. (2018). Çocuk hakları ve medya üzerine. Çocuk ve Medeniyet Dergisi, 3(5), 5-10.

Turanlı, K. (2004). Birleşmiş Milletler çocuk hakları çerçevesinde çocuğun ekonomik sömürüden korunma hakkı. (Yayınlanmamış yüksek lisans tezi). Anadolu Üniversitesi, Eskişehir.

Türkyılmaz, M. ve Kuş, Z. (2014). İlköğretim 100 temel eserde çocuk hakları. Uluslararası Avrasya Sosyal Bilimler Dergisi, 5(15), 39-63.

Ulusoy Ökeli, H. (2019). Yerel basında çocuk odaklı habercilik: Akdeniz Gerçek ve Antalya Gündem Gazeteleri üzerine bir araştırma. Global Media Journal TR Edition, 9(18), 274-293.

United Nations International Children's Emergency Fund. (2007). Çocuk hakları ve gazetecilik uygulamaları hak temelli perspektif. Dublin: Dublin Teknoloji Enstitüsü.

Uzun, R. (2014). Çocukların medyadan ve medyada korunması çocuklara yönelik etik davranış kurallarının incelenmesi. Akdeniz Üniversitesi İletişim Fakültesi Dergisi, (22), 152-167.

Washington, F. (2010). 5-6 yaş grubu çocuklarına uygulanan aile katılımlı çocuk hakları eğitimi programının etkililiğinin incelenmesi (Yüksek lisans tezi). Marmara Üniversitesi, İstanbul.

Woodhead, M. (2005). Early childhood development: A question of rights. International Journal of Early Childhood, 37(3), 79-98.

Yıldırım, A. ve Şimşek, H. (2016). Sosyal bilimlerde nitel araştırma yöntemleri. Ankara: Seçkin Yayıncllık.

Yıldız, C. (2018). Gazetede Çocuklar: Hürriyet, Sabah, Sözcü ve Posta örnekleri. Kırıkkale Üniversitesi Sosyal Bilimler Dergisi, 8(1), 281-294.

Yüksel Özmen, Ş. (2012). Çocuğun adı yok: Televizyon haberlerinde çocuğun sunumu ve çocuk hakları bağlamında değerlendirilmesi. İletişim Kuram ve Araştırma Dergisi, (34), 66- 82.

Ziyalar, N. ve Salihoğlu, S. (2008). Yazılı basında suç mağduru çocuklar. Türkiye'de Sık Karşılaşılan Psikiyatrik Hastaliklar Sempozyum Dizisi, (62), 153-156. 


\section{EXTENDED ABSTRACT}

\section{Introduction}

Mass media that can convey the information to all the parts and segments in the world has a great importance on finding out the children's place in society. As various areas in the society, in mass media, the children definitions that are presented to the society reflect the predominant child image in the society as well (İnal, 2015). The children's appearance rate on the reports and the types of reports that they are mentioned in, how they are presented, the care for the children's rights affect the perception of the individuals in the society regarding children (Yüksel Özmen, 2012). Children develop more in their childhood. So, even when they are the subject of a report, they can be abused if not cared and their development can be harmed (Doğrucan and Yıldırım, 2011). That is why this research's aim is to examine reports that involve children subjects in the printed media of the Turkish Republic of Northern Cyprus (TRNC) in accordance with the four fundamental right categories of United Nations Convention on the Rights of the Children and Sorin's (2005) child images. Subgoals are set in accordance with general purposes. Those seek answers for the questions; 'In the newspapers, what kind of reports involve children?', 'What is the level of the analyzed newspapers?', 'In the reports that involve children, what type of information is disclosed?', 'How are the children presented in the reports?', 'How are the children defined in the reports?', 'In the reports that involve children, what are the children's rights that are discussed positively?', 'In the reports that involve children, what are the children's rights that are discussed negatively?', and 'In the reports, in accordance with which child images are children reflected?'.

\section{Method}

The research has been carried out in accordance with the case study pattern, one of the research methods, to comply with the determined goals. The research sample consist of 8 newspapers published in the TRNC that has no political orientation and are chosen with the criterion sampling method which is one of the purposed random sampling methods. The data source of the research consists of reports that are published between 01.01.2019 and 01.01.2020 in the TRNC. In the scope of the research, reports searched using the keywords 'Child' and 'Children's rights' in the online archives of the newspapers have been collected with the document review method. In the research, in order to collect the reports from the websites of the newspapers searched using the keywords 'Child' and 'Children's Rights', the researcher first generated the Report Coding Form.

In the analysis of the reports involving children and children's rights in the research, the content analysis method is used. In the analysis of Sorin's (2005) 10 child images, the descriptive analysis method is used. In this analysis method, the main goal is to present the findings summarized and interpreted to the reader (Dawson, 2009). In order to measure the reliability of the Report Coding Form, Miles and Huberman (1994) reliability formulas have been applied to the data that are coded and divided into themes. The result of the formula is $91.9 \%$. The research that has been going on with the results that have been obtained by the formula is regarded as reliable.

\section{Results and Conclusion}

It is concluded that children have been mostly involved in forensic reports with 89 reports in the newspapers. Also, during the period of analysis, it is concluded that most of the reports in the newspapers consist of national reports with 148 reports. According to this, it is concluded that the reports of the newspapers analyzed for children and children's rights mostly consist of events and phenomena that involve children in the TRNC. In the findings of disclosed information about children, it is concluded that in the majority, children's information is not disclosed in 120 reports, but the most disclosed information is the age in 56 reports. It is found that gender is disclosed less than the other information in 13 reports. This situation shows that the analyzed newspapers in the TRNC see the children as children, do not marginalize them with sexism and they care about this issue. In the findings that look upon the situations in which children are defined, it is concluded that, in the analyzed newspapers, they are mostly defined as 'victims' in 
115 reports. According to the findings of analyzed newspapers, due to the neglection of the right of participation mentioned in UN Convention on the Rights of the Children and as the children have no right to speak even in the situations that concern them, children can take place in the news as victims as they are silenced. Also, only 43 positive reports are found in 217 about the children's right of protection. The number of reports in which the right of protection takes place negatively is 88 . That makes one think that children's right of protection is not minded much in situations such as neglect and accidents. In the findings looking at child images of Sorin (2005), it is seen that newspapers mostly include innocent child image in 181 reports and victim child image in 116 reports. This situation makes one think that children are used as an 'emotional subject' and by 'being made cute' in the reports.

To summarize; in the reports of the analyzed newspapers as the samples of the research, forensic reports are predominant in number. Following that, children are mostly presented as victims in the reports. This situation makes us think that; in the adverse situations the children experience, the media presents them as victims to make the situation newsworthy. In the findings looking at the rights of the children in the UN Convention on the Rights of the Children, children's right of protection has highly increased in a negative way. About this situation, it is suggested that newspapers should raise awareness about the children's rights and produce content about that in the newspapers. Also it is suggested that children's opinions are asked while making reports concerning them. 